Canadian

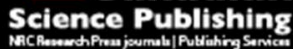

Canadian Geotechnical Journal Revue canadienne de géotechnique

\title{
Thermal conductivity of Geosynthetic Clay Liners
}

\begin{tabular}{|r|l|}
\hline Journal: & Canadian Geotechnical Journal \\
\hline Manuscript ID & cgj-2015-0585.R2 \\
\hline Danuscript Type: & Article \\
\hline Complete List of Authors: & $\begin{array}{l}\text { Ali, Mohammed; Monash University } \\
\text { Bouazza, A.; Monash University, } \\
\text { Singh, R.M.; University of Surrey, Civil and Environmental Engineering } \\
\text { Gates, Will; Monash University, Civil Engineering } \\
\text { Rowe, R. Kerry; Queens University, }\end{array}$ \\
\hline Keyword: & $\begin{array}{l}\text { geosynthetic clay liners, Thermal conductivity, vertical stress, gravimetric } \\
\text { water content }\end{array}$ \\
\hline \multicolumn{2}{|c}{} \\
\hline
\end{tabular}




\title{
Thermal Conductivity of Geosynthetic Clay Liners
}

\author{
Mohammad Asgar Ali ${ }^{1}$, \\ Abdelmalek Bouazza ${ }^{2}$, \\ Rao Martand Singh ${ }^{3}$, \\ Will P. Gates ${ }^{4}$ \\ R. Kerry Rowe ${ }^{5}$
}

${ }^{1}$ PhD Student, Department of Civil Engineering, 18 Alliance Lane, Monash University, Vic. 3800, Australia, phone: +61 39905 8901, Fax: +61 39905 4944. email: asgar.ali@monash.edu

${ }^{2 *}$ Professor, Department of Civil Engineering, 23 College Walk, Monash University, Vic. 3800, Australia, phone: +61 39905 4956, Fax: +61 399054944 email:malek.bouazza@monash.edu

${ }^{3}$ Lecturer, Department of Civil and Environmental Engineering, 24 AA 02, University of Surrey, Guildford, GU2 7XH, U.K, phone: + 44 (0)1483 68 9280, Fax: +44 (0) 148368 6041,email: r.singh@surrey.ac.uk

${ }^{4}$ Senior Research Fellow, Department of Civil Engineering, 23 College Walk, Monash University, Vic. 3800, Australia, phone: +61 3 99054664, Fax: +61 39905 4944. email:will.gates@monash.edu

${ }^{5}$ Professor and Canada Research Chair in Geotechnical and Geoenvironmental Engineering, Department of Civil Engineering, Queen's University, Ellis Hall, Kingston ON, Canada K7L 3N6, phone: +1 613 533-3113; Fax: +1 613 533-2128; email:kerry.rowe@queensu.ca 


\section{ABSTRACT}

The thermal conductivities of powdered and granular bentonite based needle punched GCLs were investigated at different gravimetric water contents under 25, 50, 75 and $100 \mathrm{kPa}$ vertical stresses, respectively. Both types of GCLs exhibited an increase in thermal conductivity with increasing vertical stress at all water contents. The effect of vertical stresses was more pronounced for the specimens hydrated at lower gravimetricwater contents and this was attributed to their high initial volumetric air content. The variability of water distribution in partially hydrated GCLs has been identified as a factor which may affect their thermal conductivity. The forms of bentonites (i.e., powder or granular) affected their thermal conductivities; however, this effect was less apparent at higher gravimetric water contents due to the reduced air content and gel formation in the bentonites. Finally, the GCL thermal conductivity, calculated from the measured thermal conductivities of its various constituents (i.e geotextile and bentonite) components, differed from the measured values. This was attributed to the non-uniform water distribution across the GCL specimen and change in material properties when components of GCL were disassembled.

Keywords: Geosynthetic clay liner, Thermal Conductivity, Vertical Stress, Gravimetric Water Content, 


\section{INTRODUCTION}

Composite liners have become an inseparable part of modern municipal solid waste landfills, fluid and mining waste containment facilities, and heap leach pads (Rowe 2005, 2014; Hornsey et al. 2010). They are typically composed of geomembranes (GMBs) and either geosynthetic clay liners (GCLs) [purpose manufactured thin-typically 5 to $10 \mathrm{~mm}$ - bentonite based materials, (Bouazza 2002; Bouazza and Gates 2014)] or compacted clay liners (CCLs). In addition to providing safe and effective containment of waste and offering the possibility of attaining very low leakage rates, composite liners must remain functional under heat transfer and heat-driven moisture transfer (Rowe 2005). These latter aspects are of increasing importance for investigation as we gain better understanding of the physico-chemical phenomenon taking place in waste containment and mining processing facilities (Southen and Rowe 2005, 2011; Rowe 2012; Abuel-Naga and Bouazza 2013; Bouazza et al. 2013, 2014; Rouf et al. 2016a) and as data gathered from temperature monitoring programs becomes accessible.

Several studies have indicated that biological decomposition of municipal solid waste in landfills generates significant heat and may raise the temperature on the lining system to $60^{\circ} \mathrm{C}$ under normal landfill operations (Yesiller et al. 2005, 2015; Rowe 2005, 2012; Koerner and Koerner 2006; Bouazza et al. 2011). Even higher temperatures, up to $70^{\circ} \mathrm{C}$, may occur at the base of landfills if there is a significant leachate mound within the landfill (Yoshida et al. 1996). In the case of aluminium production waste temperatures have been reported to reach over $80^{\circ} \mathrm{C}$ within the containment facility (Jafari et al. 2014). Composite liners in a mining environment (ex., uranium mill facility liners, heap leach pads, waste rock dumps, etc.) can be exposed to elevated temperatures (up to $80^{\circ} \mathrm{C}$ ), generated from the various ore extraction processes (Thiel and Smith 2004; Smith, 2008; Hornsey et al. 2010). Solar pond liners (e.g. in brine evaporation ponds) can also experience high temperatures ranging from $30^{\circ} \mathrm{C}$ at the surface to $90^{\circ} \mathrm{C}$ at the liner ( $\mathrm{Lu}$ et al. 2001; Silva and Almanza 2009). Similarly, storage pond liners containing some liquids generated 
from industrial and gas extraction processes can reach temperatures up to $80^{\circ} \mathrm{C}$ (and in some cases higher) due to the dual effect of solar radiation and initial liquid temperatures, with long-term ( $>5$ years) temperatures ranging between $60^{\circ} \mathrm{C}$ to $80^{\circ} \mathrm{C}$ continuously acting on the lining system (Bouazza et al. 2014). Exposed geosynthetics such as in side wall liners can also be subjected to high temperatures (up to $70^{\circ} \mathrm{C}$ ) caused solely by solar radiation (Adnan 2011; Take et al. 2012, 2015; Rentz et al. 2015). These high temperatures operating on the composite lining systems have the potential to cause intense degradation of their physico-mechanical properties which in turn may impact their service life (Rowe 2005; Abuel-Naga and Bouazza 2013).

Key to a quantification of the coupled heat-moisture transfer processes expected to occur in composite liners subjected to elevated temperatures are the thermal conductivities of the different components, since thermal conductivity controls heat transfer and temperature distribution across the composite lining system. Although a large number of thermal conductivity studies have been reported for soils and rocks (Farouki 1986; Brandon and Mitchell 1989; Abu-Hamdeh and Reeder 2000; Chen 2008; Choi et al. 2009; Abuel Naga et al. 2008, 2009; Tarnawski et al. 2011, Haigh 2012; Barry-Macaulay et al. 2013, 2014, 2015; Yu et al. 2015), there is very limited published research related to the geosynthetic components of lining systems. The scarcity of measured data has led, for example, to commonly estimating the thermal conductivities of GCLs, typically used as hydraulic barrier, based solely on the properties of the bentonite component. Only recently has data on the thermal conductivity of geosynthetics become available. Singh and Bouazza (2013) indicated that the thermal conductivity of nonwoven polyester geotextiles ranged between $0.07 \mathrm{~W} / \mathrm{mK}$ and $0.83 \mathrm{~W} / \mathrm{mK}$ depending on their water content and surface treatment. The thermal conductivity of GCLs was found to vary between $0.16 \mathrm{~W} / \mathrm{mK}$ and $1.07 \mathrm{~W} / \mathrm{mK}$, with the lowest values corresponding to the drier GCLs and the highest values to the wetter GCLs. This early work provided preliminary information on the thermal conductivities of a small number of geosynthetics routinely used in waste containment facilities. However, it also identifed knowledge gaps requiring 
attention; in particular, with respect to the effect of conditions that GCLs are subjected to (e.g., stress level, GCL gravimetric water content) on the thermal conductivities of GCLs.

The objective of this paper is to bring a greater understanding of the thermal properties of GCLs. It evaluates the evolution of thermal conductivity of GCLs that were hydrated under low vertical stress and subsequently consolidated under higher vertical stresses. The paper also examines the effect of gravimetric water content, form of the bentonite (powder or granular) on the thermal conductivity of a GCLs. Furthermore, it explores the impact of each component comprising the GCL and their contribution to the GCL thermal conductivity. Finally, it compares the thermal conductivity of powder sodium bentonite (the core component of one of the GCLs used in the present investigation) with a clayey soil, a material typically used as foundation soil in containment facilities, to highlight the importance of mineralogical composition on heat transfers.

\section{MATERIALS}

\section{Geosynthetic Clay Liners}

Two commercially available needle-punched geosynthetic clay liners (GCL-1 and GCL-2) were used in the current study. Powder sodium bentonite formed the core of GCL-1 (Elcoseal X-2000); its particle size varied from $0.3 \mu \mathrm{m}$ to $1 \mathrm{~mm}$, with $\sim 75 \%$ finer than $75 \mu \mathrm{m}(0.075 \mathrm{~mm})$. Granular sodium bentonite formed the core of GCL-2 (Bentomat ST), its dry-granule particle size varied from $75 \mu \mathrm{m}$ to $2.2 \mathrm{~mm}$ and had very small amount of fines $\leq 75 \mu \mathrm{m}$. The average particle size $\left(\mathrm{D}_{50}\right)$ of the bentonite was $0.035 \mathrm{~mm}$ in GCL-1, and $0.9 \mathrm{~mm}$ in GCL-2. GCL-1 had a nonwoven polypropylene geotextile cover layer and a nonwoven polypropylene geotextile with a woven scrimreinforced carrier and was thermally treated. GCL-2 had a nonwoven polypropylene geotextile cover layer and a woven polypropylene geotextile carrier. The physical characteristics of the specimens (based on 20 specimens of equal size, $75 \mathrm{~mm}$ diameter, randomly taken from each GCL roll) are summarized in Table 1 . The mass per unit area of bentonite $\left(\mathrm{M}_{\mathrm{b}}\right)$ was calculated as the difference between the total mass per unit area of GCL (MCL; ASTM D5993) and mass per unit 
area of geotextiles $\left(\mathrm{M}_{\mathrm{b}}=\mathrm{M}_{\mathrm{GCL}}-\mathrm{M}_{\mathrm{GU}}-\mathrm{M}_{\mathrm{GL}}\right)$. The distribution of the mass per area of both GCLs is presented in Figure 1 (a) and (b). These figures indicate that a GCL specimen with a mass per area 4.91 5.15 kg/m² may be considered representative of the roll (for both GCLs) for the selected size. Therefore, only specimens with mass per area within this range were used in this study.

\section{Bentonites}

Bentonite was collected from each GCL by carefully peeling off the geotextile components. Precautions were taken so that the collected bentonite was free of fibres. The bentonite obtained from GCL-1 and GCL-2 are referred to herein as Bentonite-1 and Bentonite-2, respectively. These bentonites were used to prepare bentonite cakes $(75 \mathrm{~mm}$ diameter) at various gravimetric water contents. Mineralogical compositions of both bentonites are presented in Table 2.

\section{Geotextiles}

The cover and carrier geotextiles of GCL-1 were carefully separated from each other and the bentonite. Each geotextile was cleaned thoroughly to remove all adhering bentonite particles. Circular geotextile specimens with $75 \mathrm{~mm}$ diameter were prepared for thermal conductivity analysis.

\section{Clayey material}

The clayey material (CH-according to USCS classification) was sourced from a site where a liquid storage pond was to be constructed. It had a liquid limit (LL) of 57\%, plastic limit (PL) of 27\% and specific gravity $\left(\mathrm{G}_{\mathrm{s}}\right)$ of 2.66 . It contained mostly fine grained soil particles with $82 \%$ particles finer than 60 micron and had significant amount of smectite. The mineralogical composition of the clayey soil, denoted as Clay-1, is presented in Table 2.

\section{HYDRATION CHARACTERIZATION OF GCLS AND BENTONITE CAKES}

\section{Hydration characterisation of GCLs}

The water uptake capacity of GCLs is important to quantify since it gives an indication on the length of time needed for a GCL to reach full hydration under specific loading conditions. It was measured for both GCL-1 and GCL-2 under vertical stresses of 25, 50, 75 and $100 \mathrm{kPa}$ in the 
following way: A GCL specimen of $75 \mathrm{~mm}$ diameter was cut from a GCL roll and its mass per area was checked to ensure it met the criteria given in Figure 1. Upon satisfying the criteria, silicone paste was applied to its periphery to prevent possible loss of bentonite from the specimen during the hydration process. The specimen was then preserved for 24 hours to allow for the silicone to harden and adhere to the specimen. Next it was placed on a porous stone, sitting in a consolidation cell. The cell was set up to apply the target vertical load on the specimen and distilled water was added into the cell. The specimen mass was regularly checked by removing it from the cell, weighing it, and returning it very quickly to the cell. The test was discontinued when no further change in the specimen mass was observed. The water uptake of both GCL types varied with the applied stress (Figure 2) with the maximum gravimetric water contents of both GCLs decreasing with an increase in vertical stress. This behaviour can be attributed to the restrained swelling characteristics of the GCL and reduction of available pore spaces in bentonite layer under higher vertical stresses (Lake and Rowe 2000; Bannour et al. 2014; Rouf et al. 2016a). The maximum hydration gravimetric moisture content $\left(\mathrm{w}_{\mathrm{ref}}\right)$ for each of the GCLs was taken to be the final equilibrium moisture content. Table 4 summarizes the $\mathrm{w}_{\text {ref }}$ for each GCL and for each loading condition.

\section{Bentonite cake preparation and hydration characterisation}

For comparison, between thermal conductivity of GCL and its constituent bentonite, bentonite cakes were prepared. It is mentionworthy that the cakes were prepared under a vertical stress of 25 $\mathrm{kPa}$, at various water contents with both powder and granular bentonites, to compare their thermal conductivity with their parent GCLs thermal conductivity (subjected to $25 \mathrm{kPa}$ load) under identical condition. . The bentonite cake represented the bentonite core of GCL specimen. The total amount of bentonite $(\sim 18.6 \mathrm{~g})$ used to prepare the cake was estimated to produce a mass per unit area of $4.22 \mathrm{~kg} / \mathrm{m}^{2}$ (for both type of bentonites) based on the information provided in Table 1. An initially dry porous stone surrounded by $75 \mathrm{~mm}$ ring was placed at the base of a consolidation cell. A filter paper was placed on the porous stone. Then a predetermined amount of bentonite (18.6 g) was poured into the ring. Care was taken to spread the bentonite uniformly across the filter paper within 
the ring. The bentonite was then covered by another filter paper and the top cap of the consolidation cell. The cell was then set up to apply $25 \mathrm{kPa}$ vertical stress to the specimen. A vertical displacement transducer was connected to the top cap before water was added to the consolidation cell. The swelling was recorded from the start of hydration until no further swelling was observed (Figure 3). With the same mass of bentonite and applied stress, the swelling of granular bentonite was less than that of powder bentonite (Figure 3). This behaviour can be attributed to the collapse of the granular structure upon wetting and parallel expansion of individual granule to fill up intergranular gaps with water uptake by granular bentonite (Alonso et al. 2011). The test was repeated several times under identical conditions but terminated at different time intervals to establish the gravimetric water content vs time relationship for each bentonite cake (Figure 4). The water absorption by both bentonites was quick at the intial stage and then slowed gradually (Figure 4) as previously reported by Vangpaisal and Bouazza (2004). These figures were used as a guide to prepare bentonite cakes at targeted water contents.

\section{DEVELOPMENT AND OPERATION OF A THERMO-CELL}

The development of the thermal conductivity laboratory set up (thermo-cell; Figure 5) used in this study was based on the guarded-comparative-longitudinal heat flow technique, which employs a steady state method to obtain the thermal conductivity of homogeneous solids (Barry-Macaulay et al. 2013). The thermo-cell consisted of two temperature controlled plates located at the top and bottom of the cell. The bottom plate contained an electric heater which generated a controllable heat source at constant temperature, while cool water was circulated through the top plate from a temperature controlled water bath. The GCL specimen (75 mm diameter), inserted between two identical heat flux sensors or meter-bars of known thermal properties and of the same diameter as the GCL specimen, was placed between the heater (at the bottom) and a heat sink (at the top). The two heat flux sensors were manufactured by placing a $1 \mathrm{~mm}$ polycarbonate (thermal conductivity 0.19 0.21 W/mK) disc sandwiched between two $3 \mathrm{~mm}$ aluminium discs (thermal conductivity 
205 210 W/mK) to form a meter-bar (7 mm thick). Holes were drilled in the aluminium discs at mid-depth but continued to the centre of the discs to allow insertion of two thermocouples $(0.1 \mathrm{~mm}$ diameter), one above the polycarbonate sheet and one below it. The thermocouples were connected to a computer through a data logger so that temperature of the two materials could be monitored continuously when subjected to a thermal gradient. The whole system was then encased into a polytetrafluroethylene (PTFE) (thermal conductivity $0.18 \sim 0.20 \mathrm{~W} / \mathrm{mK}$ ) cylinder to minimize radial heat loss. Once the assembly of the thermo-cell was completed it was placed in an automated loading frame capable of applying vertical stresses incrementally. A displacement transducer was attached to the frame so that vertical compression of the specimen could be monitored when stress was applied. It is to be noted that water was allowed to drain from the GCL specimen when undergoing consolidation. The thermal gradient was applied only once consolidation was completed. The thickness of the encasing PTFE cylinder was $25 \mathrm{~mm}$. The inner diameter of the cylinder was 75 $\mathrm{mm}$, which was equal to the diameter of the specimen. Thus, the GCL specimens were expected to undergo zero radial strain when subjected to vertical stresses.

Once the thermal gradient was applied to the test stack, the temperatures in the meter-bars were monitored until equilibrium was reached. The thermal conductivity was then calculated from the measured temperature gradient in the specimen and the thermal conductivity of the reference material (i.e., polycarbonate) using the following equation:

$\lambda=\lambda_{\mathrm{r}} * \frac{\Delta \mathrm{T}_{1}+\Delta \mathrm{T}_{2}}{2 * \Delta \mathrm{T}_{\mathrm{s}}} * \frac{\mathrm{L}}{\mathrm{L}_{\mathrm{r}}}$

where, $\lambda=$ thermal conductivity of the GCL specimen $\left({ }^{\circ} \mathrm{W} / \mathrm{mK}\right) ; \lambda_{\mathrm{r}}=$ thermal conductivity of reference material (i.e., polycarbonate) $(0.2 \mathrm{~W} / \mathrm{mK}) ; \Delta \mathrm{T}_{1}=$ temperature gradient across one meterbar $\left({ }^{\circ} \mathrm{C}\right) ; \Delta \mathrm{T}_{2}=$ temperature across the second meter-bar $\left({ }^{\circ} \mathrm{C}\right) ; \Delta \mathrm{T}_{\mathrm{S}}=$ temperature gradient across the test specimen $\left({ }^{\circ} \mathrm{C}\right) ; \mathrm{L}=$ thickness of the test specimen $(\mathrm{m})$, and $\mathrm{L}_{\mathrm{r}}=$ thickness of the reference material (m). 
Two assumptions were made in developing the test set-up and calculating the thermal conductivity of the GCL specimens. First, it was assumed that heat movement took place only in vertical direction with no radial heat losses. It is thermodynamically difficult to achieve zero radial heat loss but loss was minimised by wrapping the test stack with a PTFE cylinder. Second, it was assumed that the total temperature drop across the aluminium discs of the test setup was negligible compared with the drop across the polycarbonate and the specimen. This assumption is acceptable due to the low thermal resistance of the aluminium discs.

\section{Conditioning GCL and its components for thermal conductivity test}

This study aims to estimate the thermal conductivityof GCLs, subjected to different vertical stresses (i.e. $25,50,75$ and $100 \mathrm{kPa}$ ), at three different gravimetric water contents namely 80,120 and $140 \%$ for GCL-1 and 75, 100 and 125\% for GCL-2, which have been collectively referred to as target gravimetric water contents in this paper. Calibration tests, run separately to quantify the loss of water in response to the application of vertical stresses, indicated that the specimens had to be hydrated to specific gravimetric water contents so that the final gravimetric water content of the specimens (after the loss of water due to the applied vertical stresses) remained close the target gravimetric water content. Thus, the preparation of the GCL specimens followed a specific procedure aimed at achieving specific gravimetric water contents that were consistent with the target gravimetric water contents. The procedure involved hydration to the specific gravimetric water content, consolidation at given vertical stress, and gravimetric water content recheck to verify that the target gravimetric water content was achieved. Hence, the process involved the following: a number of specimens were initially hydrated, under $2.5 \mathrm{kPa}$ stress, by placing them on soaked porous stones partially submerged into water (bottom-up hydration process). Once the specific gravimetric water content was reached the specimens were removed from the water uptake set up and stored in a triple re-sealable plastic bag for two weeks to ensure a uniform distribution of water in the GCL specimens (Bouazza and Vangpaisal 2003; Vangpaisal and Bouazza 2004; Acikel et al. 
2015; Rouf et al. 2016a,b). The next stage involved placing the specimen in the thermo-cell and applying the target vertical stresses (range 25 to $100 \mathrm{kPa}$ ) but with no applied thermal gradient. It is to be noted that drainage was allowed when the GCL specimens were consolidated. Once the specimen reached equilibrium under the selected applied stress, the set up was dismantled and the specimen gravimetric water content was re-checked. This process was repeated until the satisfactory target gravimetric water content could be achieved under a given vertical stress.

Thus for the thermal conductivity tests, the specimens' (conditioned as described above) initial gravimetric water contents were carefully chosen so that the target gravimetric water contents could be closely approximated. The target, measured initial (before applying load), intermediate (before applying temperature gradient) and final gravimetric water contents of the specimens at given vertical stresses are presented in Table 3 . Thermal conductivity was measured at $\Delta \mathrm{T}=10^{\circ} \mathrm{C}\left(30^{\circ} \mathrm{C}\right.$ at the bottom and $20^{\circ} \mathrm{C}$ at the top of test stack) to minimize water loss during the test. The water loss of the specimens, when subjected to thermal gradient, remained within a narrow range $(0.06 \%$ $\sim 0.85 \%$; Table 3 ).

Circular geotextile specimens (after being parted from the GCL as described in the materials section) were immersed into distilled water, contained in a desiccator. The specimens were placed at the base of desiccator with a sitting load $(\sim 10 \mathrm{~g})$ on them. They were taken out of the desiccator at various times to measure their thermal conductivity at various water contents. The bentonite cakes were prepared at the target gravimetric water content as described in the hydration section prior to placing in the the thermo-cell for thermal conductivity tests

\section{RESULTS AND DISCUSSION}

\section{Thermal conductivity vs vertical stress:}


The GCL thermal conductivity increased with increasing vertical stress at each target gravimetric water content (Figure 6). However, experimental data suggest that at least two parameters changed when an applied vertical stress was increased. These two parameters were the number of contacts between solid particles within the specimen and the bulk void ratio, $e$, of the specimen. The bulk void ratio is defined as the ratio of the bulk volume of voids to volume of solids in the hydrated GCL and can be calculated based on Petrov and Rowe (1997), as:

$e=\frac{H_{G C L}-H_{S}}{H_{S}}$

$H_{S}=\frac{M_{B E N T}}{\rho_{B E N T}}+\frac{M_{G U}}{\rho_{G U}}+\frac{M_{G L}}{\rho_{G L}}$

where, $e$ is the bulk void ratio; $H_{G C L}$ is the hydrated GCL height; $H_{s}$ is the height of the solids (bentonite and geotextiles); $M_{B E N T}$ is the dry mass per unit area of bentonite; $M_{G U}, M_{G L}$ are the mass per unit area of upper and lower geotextiles and $\rho_{B E N T}, \rho_{G U}, \rho_{G L}$ are the density of bentonite, upper geotextile, and lower geotextile, respectively.

Changes to the void ratio of the specimens with increasing vertical stress were quantified (following the procedure described above) and are shown along with relevant thermal conductivities in Figure 7. The data clearly indicate that the thermal conductivity was impacted by the hydration state and vertical stress, both of which affected the bulk void ratio. The decrease in the void ratio, as a result of increased vertical stress, implies densification of soil structure. For each set of specimens, the gravimetric water content (when subjected to a temperature gradient) and mass per area were within a very narrow range (Table 3) while the void ratio of the specimen varied based on the imposed vertical stress.

Farouki (1986) reported that the thermal conductivity of any soil-like material depended on its structure, the number and nature of contacts between solid particles, and the volumetric fraction of any water, or gas phases associated with pores within, or between, the solid phases. Tang et al. 
(2008) and Xie et al. (2012) explored the effect of dry density and water content on the thermal conductivities of compacted bentonites. These studies concluded that an increase in the number of inter-particle contacts and water content improved heat transfer ability through porous media. From the experimental evidences shown in the present study, it can be hypothesized that the increase in vertical stress reduced the pore space of the specimen and increased the number of contacts between solids. Both of these changes enhanced heat transmission through the specimen and thus increased the thermal conductivity as was noted by Barry-Macaulay et al. (2013) for different soils.

It can also be observed from Figure 6 that for a given stress, the specimens at higher gravimetric water contents had a higher thermal conductivity despite having a similar mass of material per unit area (before hydration). Although heat flows mainly through the solid particles, it is also required to bridge the gaps around the contact points. If the gap is filled up with air, which has a very low thermal conductivity $(0.02 \mathrm{~W} / \mathrm{mK})$, some heat is lost to bridge the gaps. But if the gap is filled with water, which has much higher thermal conductivity $(0.6 \mathrm{~W} / \mathrm{mK})$ than air, a highly conductive bridge between the particles exists and thus the thermal conductivity of the system tends to increase. Hence, the thermal conductivity of fluid that fills the gaps between particles affects the thermal conductivity of the material as a whole. It can therefore be conceptualized that an increased gravimetric water content would improve the thermal contact between the solid particles which in turn increases the thermal conductivity as was observed in the present study.

It was also observed that changes in thermal conductivity with increasing stress were more pronounced for specimens with lower gravimetric water content (i.e., S1, S4 specimens) than the specimens with a higher gravimetric water content. This can be attributed to the considerable reduction in bulk void ratio of the specimens under similar increment in vertical stresses (Figure 7). The specimens hydrated at the lowest gravimetric water content have higher initial volumetric air content. Therefore it can be reasonably assumed that increased vertical loads imposed greater reduction in bulk void ratio in these specimens, compared to specimens hydrated to higher 
gravimetric water contents, by forcing out air voids. A higher reduction in void ratio implies greater densification of solid particles which results in significant rise in heat transmission capacity.

\section{Thermal conductivity vs apparent degree of saturation}

The apparent degree of saturation $\left(\mathrm{S}_{\mathrm{r}}{ }^{*}=w / w_{r e f}\right)$ for any particular specimen is defined as the gravimetric water content $(w)$ of a GCL divided by the maximum gravimetric water content $\left(w_{r e f}\right)$ that the same GCL reached during hydration under the same applied stress conditions (Rayhani et al. 2011; Anderson et al. 2012; and Singh and Bouazza 2013). The $w_{\text {ref }}$ values for the GCLs under various vertical stresses are given in Table 4.

Changes in thermal conductivity with apparent degree of saturation for both types of GCLs are reported in Figure 8. This figure shows that thermal conductivity increased with increased apparent degree of saturation. It can also be observed that the incremental increases in thermal conductivity were greater at low saturation $\left(\mathrm{S}_{\mathrm{r}}<50 \%\right)$ (i.e low gravimetric water content). This can be ascribed to the reactivity of bentonite particles under these experimental conditions. Pusch (1982) explored the response of bentonite particles during and after water uptake (from initial air-dry to completely saturated condition) and found that bentonite particles became plastic and started to swell upon hydration. Therefore, hydration induced swelling can result in increased inter particle contacts. This will lead to a rapid increase in thermal conductivity with the increase in water content as observed at the initial stage shown in Figure 8. With further water uptake, bentonite swells more and transforms from an aggregated to a more homogeneous, dispersed state (Pusch 1980, 1982; Börgesson 1985). At this stage inter particle contact does not change significantly leading to more gradual and slower increase in thermal conductivity as observed in Figure 8.

There was some variability in the thermal conductivities of the specimens, especially for those hydrated to lower gravimetric water contents (Figure 8). This scatter could be due to the randomness of water distribution within the unsaturated GCL specimen. It has been commonly 
accepted that bentonite form tends to impact on water uptake of GCLs. Vangpaisal and Bouazza (2004) indicated that at the beginning of hydration, the outermost layer of dry bentonite in a powdered bentonite based GCL, absorbs water and swells. The inner dry layers then gradually take water from the wetting front until the water potential among the layers has equilibrated. Vangpaisal and Bouazza (2004) also reported that during hydration of granular bentonite, the large voids between the bentonite granules are filled first and then the clay particles within the granules take in water until water potential is equalized. Not all the pores in an unsaturated GCL are filled with water. Thus it can be reasonably assumed that the spatial distribution of water in such specimens is controlled by the water potential of the solid matrix (i.e. the matrix potential), which is a function of the pore distribution within the specimen. It is practicable to consider that the distribution of bentonite particles in GCL specimens at as-received condition is quite random. These bentonite particles swell anisotropically upon water uptake. This anisotropic swelling can be attributed to the difference in axial and radial stresses acting upon bentonite particles (Lee et al. 2012; Saba et al. 2014). Thus it is expected that the pore structure and distribution of pores in the bentonite reorganise upon hydration (Börgesson 1985; Katsumi et al. 2008; Pusch 1982; Wang et al. 2012), depending on the amount and types of stresses experienced. With continuing hydration, the bentonite particles will continue swelling and any resulting microstructural change will decrease the initial anisotropy leading to the formation of mostly homogeneous bentonite gels (Börgesson 1985; Kanno and Wakamatsu 1992; Pusch 1980, 1982). It can therefore be logically inferred that pores are randomly oriented in the bentonite core of an unsaturated GCL (before formation of gel) and that this impacts the spatial distribution of water in a low water content GCL.

\section{GCL vs bentonite cake}

Thermal conductivities of bentonite cakes were obtained at different gravimetric water contents and are plotted along with those for the parent GCLs in Figure 9. As the bentonite cakes were prepared under $25 \mathrm{kPa}$ stress, the thermal conductivities of GCL specimens, measured under $25 \mathrm{kPa}$ stress, have been reported for comparison under identical condition. The results indicate that thermal 
conductivity of bentonite was higher than that of its GCL counterpart for a similar mass of bentonite per unit area. The GCL is a composite material where bentonite is contained between two layers of geotextiles. The parent material of the geotextile is polypropylene whose thermal conductivity $(0.12 \sim 0.34 \mathrm{~W} / \mathrm{mK})$ is substantially lower than that of smectite $(1.8 \mathrm{~W} / \mathrm{mK})$, which is the primary component of bentonite clay; and therefore, the heat transfer capability of bentonite is significantly reduced when combined with geotextiles.

\section{Powder vs granular bentonite}

The thermal conductivities of two types of bentonites are compared in Figure 10. To better assess the trends in the data reported in this Figure, the experimentally evaluated thermal conductivities were fitted by regression models. Based on the coefficient of determination $\mathrm{R}^{2}$ values it can be said that both models fit reasonably well with the given set of data. The regressions suggest that any difference in thermal conductivities of the bentonites is most likely observed at lower gravimetric water contents. This difference may be attributed to their forms. Bentonite-1 (powdered bentonite) has a higher exposed surface area, which means higher inter particle contacts, in comparison to Bentonite-2 (granular bentonite). Bentonite-2, because of its form, has large voids and consequently poorer inter granular contacts. Thus, Bentonite-1 has a better heat transfer capability than Bentonite-2, especially at lower gravimteric water contents. This finding agrees well with Singh and Bouazza (2013).

The regression equation for Bentonite-2 has greater slope (0.0057) than that for Bentonite-1 (0.0039) over the range of data examined herein. A greater slope indicates a higher change in thermal conductivity in response to a change in gravimteric water content. This behaviour is, most likely, due to the change in the micro structure of the granular bentonite with the increase in water content. During the hydration of granular bentonite, the voids between the bentonite granules across the entire thickness are immediately filled with water (Vangpaisal and Bouazza 2004). Thus the outer surfaces of each individual granule wet initially, and clay particles within the granules then wet more slowly. As the hydration of the granule continues, the stiffness and inter-granular shear 
resistance, which stabilise the global microstructure of the granule prior to hydration, decreases. This results in overall collapse of the granular structure (Hoffmann et al. 2007). Therefore, once fully hydrated, granular bentonites form an open and mostly homogeneous gel network within the inter-granular space (Pusch 1980; Pusch and Hokmark 1990) which is effectively the same as that of powder bentonite. In the light of the above discussion, it can be inferred that the contacts between solids in Bentonite-2 improved significantly with the increase in gravimetric water content and thus leading to a reduction in the difference in thermal conductivity between the two bentonites..

\section{Bentonite vs clayey soil}

Heat transmission ability of Bentonite-1, in the form of bentonite cake was compared with that of Clay-1. The thermal conductivity of Clay-1 was reported in Bouazza et al. (2014). Variation in thermal conductivities of both Clay-1 and Bentonite-1 with gravimetric water content are summarized in Figure 11. The data sets of both materials were fitted by regression models. The regressions indicate that heat transferring ability of Clay-1 is greater than that of Bentonite-1 for similar gravimetric water contents. The difference can be ascribed to bulk mineralogy of the materials. It has been commonly accepted that thermal conductivity of a soil type material is largely influenced by its mineralogy (Barry-Macaulay et al. 2013). Of the common minerals, quartz has the highest heat conductivity $(7.8 \mathrm{~W} / \mathrm{mK})$ whereas heat transmission capacity of smectite $(1.8 \mathrm{~W} / \mathrm{mK})$ is around one-quarter of that of quartz (Horai 1971). Barry-Macaulay et al. $(2013,2015)$ have also indicated that quartz content tends to dominate the thermal conductivity of soils and rocks.

The bulk mineralogy of the materials presented in Table 2 indicates that quartz content of Clay- 1 $(53 \%)$ is significantly higher than that of Bentonite-1 $(14 \%)$; while the primary component of Bentonite-1 is smectite (74\%) which is less heat conductive. Therefore, it can be concluded that the mineralogical composition is the primary factor responsible for Clay-1 being more heat conductive than Bentonite-1. 


\section{Different components of GCL-1}

The thermal conductivities of the different components (carrier and cover geotextile, bentonite) of GCL-1 were evaluated at varying gravimetric water contents. These values were used to estimate the GCL thermal conductivity by taking the weighted average of its components and then compared with the value measured in the laboratory under similar conditions. The estimated and measured values along with the measured thermal conductivities of each component are presented in Figure 12. There was a notable dissimilarity between measured and estimated values of thermal conductivity for GCL-1 (Figure 12). One possible reason for this difference could be the water distribution across the GCL thickness. GCL-1 specimens were triple bagged for at least two weeks after they had been hydrated to attain water equilibrium across the specimen. The negative water potential of the bentonite core within a GCL is significantly greater than that of a geotextile (Abuel Naga and Bouazza, 2010). Therefore, it can be reasonably assumed that during the pre-conditioning period the bentonite core would have taken water from the geotextiles, thereby reducing its heat conductance relative to geotextile at its original water content. Both the cover and carrier geotextiles reduced heat flow when the specimen was subjected to temperature gradient and thus led to lower thermal conductivity of the GCL-1 as a unit. On the other hand, all the components of GCL-1 were assumed to have the same water contents when the thermal conductivity was estimated. To address this, the estimation process was revised and assumed a worst case scenario where the geotextiles (both carrier and cover) remained in a nearly dry condition (with a thermal conductivity of $0.18 \mathrm{~W} / \mathrm{mK}$ for the cover and $0.15 \mathrm{~W} / \mathrm{mK}$ for the carrier geotextile as measured in the laboratory at $<1 \%$ water content). The resulting estimated GCL thermal conductivity (Figure 13) was still well above the measured value even with this "worst case" assumption. Thus, an unequal water distribution across the specimen appears to not be the only cause for the difference observed. Another reason may be that there were changes in material properties when the individual components were separated from the GCL to perform the thermal conductivity tests. For example, the bentonite cakes used didn't have any entrained fibres, whereas in the intact GCL specimens a 
substantial amount of fibres run through or are entangled within the bentonite core, especially when partially or fully hydrated. The absence of fibres ensured that inter-particle contact was better in the bentonite cake than it was in the GCL specimen, thus no attenuation of thermal conductivity of the bentonite by the fibres. Also, the detached cover and carrier geotextiles did not contain any bentonite particles whereas these geotextiles were impregnated with bentonite in the GCL specimen. Some geotextile fibres were damaged when they were parted from GCL. All these factors combined would have introduced a notable difference between estimated and measured thermal conductivity of GCL. A plot of the measured thermal conductivity of GCL-1 against the revised thermal conductivity (Figure 14) indicates a linear correlation between these values. This suggests that the combined effects of all the above mentioned factors remained irrespective of the change in gravimetric water content, at least within the range of water contents investigated.

\section{GCL-1 vS GCL-2:}

The thermal conductivity variation against the apparent degree of saturation of both GCLs is shown in Figure 15. This figure indicates that the thermal conductivity of GCL-2 is, generally, lower than that of GCL-1 at a similar apparent degree of saturation. The structure of the GCL (i.e. thermal treatment, fibres density, and bentonite form) tends to govern this variation. Similar observations were reported by Singh and Bouazza (2013) for similar types of GCLs under free swell conditions. Interestingly, the changes in thermal conductivity of the GCLs were not similar to the changes exhibited by their constituent bentonites shown in Figure 10. This dissimilarity is most probably related to the fact that the GCL is a composite material where the different components (i.e. geotextiles, fibres, bentonite) play a role in the variation of thermal conductivity as shown in the current study compared to a more homogeneous material such as bentonite. Hence, it can be concluded that thermal conductivity of different types of GCLs cannot be compared solely based on thermal conductivity of their constituent bentonites; GCL structure, density of fibres, thermal 
conductivity of the geotextiles, and amount of bentonites impregnated into the geotextiles should be taken into consideration for a meaningful comparison.

\section{CONCLUSIONS}

A thermo-cell has been developed to measure thermal conductivity under various vertical stresses. Thermal conductivity of a powdered and a granular bentonite based GCL was obtained under 25, 50, 75 and $100 \mathrm{kPa}$ vertical stresses at three gravimetric water contents. For the materials and conditions examined in this paper, it is concluded that:

1. For a given gravimetric water content, the increase in vertical stress caused an increase in thermal conductivity. This was attributed to physical changes induced by vertical stress; namely, improved inter-particle contacts and densification of specimen. Both these changes can be expected to enhance heat conduction through solid particles and thus contribute to an increase in the thermal conductivity of the GCL as a whole.

2. The effect of stress was more pronounced for the specimens with lower gravimetric water contents. This behaviour was attributed to greater reduction in bulk void ratio of these specimens with the imposed vertical stress.

3. For a given stress, the higher the gravimetric water content, the higher the thermal conductivity. This was attributed to enhanced thermal contact between the particles contact points as gravimetric water content increased..

4. Thermal conductivity of GCL increased with increases in the apparent degree of saturation; the incremental increases in thermal conductivity were greater at lower water contents $\left(\mathrm{S}_{\mathrm{r}}<50 \%\right)$. This behaviour has been ascribed to the significant improvement in contacts between solid particles induced by bentonite swelling upon water uptake.

5. More variations in the thermal conductivities of the GCL specimens was observed when they were hydrated to lower water content. This was attributed to variability of water distribution within the specimen. 
6. Powder bentonite had a higher thermal conductivity than that of granular bentonite. However, the difference between the two decreased at higher gravimteric water contents. Thermal conductivity of different GCLs cannot be compared only based on thermal conductivity of their constituent bentonites; rather the combined effect of GCL structure, density of fibres, thermal properties of geotextiles and amount of bentoniteimpregnated into the geotextiles should be considered for better comparison.

7. The mineralogical composition of the clay materials affected their thermal conductivity. The clayey soil (clay-1) with the higher quartz content had a higher thermal conductivity than that with low quartz content (Bentonite-1).

8. Thermal conductivity of a GCL estimated from thermal conductivities of its components was significantly higher than that measured. The difference was attributed to unequal water distribution among the components after hydration as well as the change in material properties when the GCL was split up into individual components.

\section{ACKNOWLEDGEMENTS}

This study was supported under the Australian Research Council's Discovery Projects funding scheme (project number DP130100203). The authors' sincere appreciation is extended to the council. The anonymous reviewers made many constructive comments and valuable suggestions. These comments and efforts associated with the review are greatly appreciated by the authors.

\section{REFERENCES}

Abu-Hamdeh, N.H. and Reeder, R.C. 2000. Soil thermal conductivity: effects of density, moisture, salt concentration, and organic matter. Soil Science Society of America Journal 64(4): 12851290.

Abuel-Naga, H., and Bouazza, A. 2010. A novel laboratory technique to determine the water retention curve of geosynthetic clay liners. Geosynthetic International 17(5): 313-322.

Abuel-Naga, H., and Bouazza, A. 2013. Thermomechanical behaviour of saturated geosynthetic clay liners. Journal of Geotechnical and Geoenvironmental Engineering, 139(4): 539-547. 
Abuel-Naga, H., and Bouazza, A. 2014. Numerical experiment-artificial intelligence approach to develop empirical equations for predicting leakage rates through GM/GCL composite liners. Geotextiles and Geomembranes, 42(3):236-245.

Abuel-Naga, H.M., Bergado, D.T., and Bouazza, A. 2008. Thermal conductivity evolution of saturated clay under consolidation process. International Journal of Geomechanics, 8(2): 114122.

Abuel-Naga, H.M., Bergado, D.T., and Bouazza, A. 2009. Laboratory and field thermal conductivity of a saturated clay. Engineering Geology, 105 (3-4): 211-219.

Acikel, A., Singh, R.M., Bouazza, A., Gates,W.P., and Rowe, R.K. 2015. Applicability and accuracy of the initially dry and initially wet contact filter paper tests for matric suction measurement of geosynthetic clay liners. Geotechnique, 65(9):780-787.

Adnan, M. 2011. Assessment and analysis of temperature monitoring data of a geomembrane liner subjected to solar radiation. Final Year Dissertation, Monash University, Melbourne, Australia, unpublished.

Alonso, E.E., Romero, E. and Hoffmann, C. 2011. Hydromechanical behaviour of compacted granular expansive mixtures: experimental and constitutive study. Geotechnique 61(4): 329344

Anderson, R., Rayhani, M.T., and Rowe, R.K. 2012. Laboratory investigation of GCL hydration from clayey sand subsoil. Geotextiles and Geomembranes 31: 31-38.

ASTM D5993-14 2014. Standard test method for measuring mass per unit of geosynthetic clay liners, ASTM International, West Conshohocken, PA, USA, www.astm.org

Bannour, H., Stoltz, G., Delage, P., and Touze-Foltz, N. 2014. Effect of stress on water retention of needle punched geosynthetic clay liners. Geotextiles and Geomembranes, 42: 629-640

Barry-Macaulay, D., Bouazza, A., Singh, R., Wang, B., and Ranjith, P.G. 2013. Thermal conductivity of soils and rocks from Melbourne (Australia) region. Engineering Geology, 164: 131-138.

Barry-Macaulay, D., Bouazza, A., Singh, R.M., and Wang, B. 2014. Thermal properties of some Melbourne soils and rocks. Australian Geomechanics Journal, 49(2): 31-44

Barry-Macaulay, D., Bouazza, A., Wang, B., and Singh, R.M. 2015. Evaluation of soil thermal conductivity models. Canadian Geotechnical Journal, 52(11): 1892-1900

Börgesson, L. 1985. Water flow and swelling pressure in non-saturated bentonite-based clay barriers. Engineering Geology, 21(3-4): 229-237.

Bouazza, A. 2002. Geosynthetic clay liners. Geotextiles and Geomembranes 20(1): 3-17.

Bouazza, A., and Vangpaisal, T. 2003. An apparatus to measure gas permeability of geosynthetic clay liners. Geotextiles and Geomembranes, 21(2): 85-101. 
Bouazza, A., and Gates, W.P. 2014. Overview of performance compatibility issues of GCLs with respect to leachates of extreme chemistry. Geosynthetics International, 21(2):1-17.

Bouazza, A., Nahlawi, H., and Alyward, M. 2011. In-situ temperature monitoring in an organic waste landfill cell. Journal of Geotechnical and Geoenvironmental Engineering 137 (12): 12861289.

Bouazza, A., Zornberg, J., McCartney, J., and Singh M.R. 2013. Unsaturated geotechnics applied to geoenvironmental engineering problems involving geosynthetics. Engineering Geology, 165: $143-153$.

Bouazza, A., Singh, R.M., Rowe, R.K. and Gassner, F. 2014. Heat and moisture migration in a geomembrane-GCL composite liner subjected to high temperatures and low vertical stresses. Geotextiles and Geomembranes 42: 555-563

Brandon, T.L., Mitchell, J.K., and Cameron, J.T. 1989. Thermal instability in buried cable backfills. Journal of Geotechnical Engineering 115(1): 38-55.

Chen, S.X. 2008. Thermal conductivity of sands. Heat Mass Transfer, 44 (10): 1241-1246.

Choi, J.W., Kwon, S., and Cho, W.J. 2009. The thermal conductivity for granite with various water contents. Engineering Geology, 107(3-4): 167-171

Delage, P., and Lefebvre, G. 1984. Study of the structure of a sensitive Champlain clay and its evolution during consolidation. Canadian Geotechnical Journal, 21(1): 21-35.

Farouki, O. T. 1986. Thermal properties of soils. Series on Rock and Soil Mechanics. Trans Tech Publications, Clausthal-Zellerfeld, Vol. 11.

Griffiths, F. J., and Joshi, R. C. 1990. Clay fabric response to consolidation. Applied Clay Science 5(1): 37-66.

Haigh, S.K. 2012. Thermal conductivity of sands. Géotechnique, 62 (7): 617-625

Hoffmann, C., Alonso, E. E., and Romero, E. 2007. Hydromechanical behaviour of bentonite pellet mixtures. Physics and Chemistry of the Earth 32 (8-14): 832-849.

Horai, K. 1971. Thermal conductivity of common rock forming minerals. Journal of Geophysics, 76(5): 1278-1308

Hornsey, W.P., Scheirs, J., Gates, W.P., and Bouazza, A. 2010. The impact of mining solutions/liquors on geosynthetics. Geotextiles and Geomembranes 28(2): 191-198

Jafari, N.H., Stark, T.D., and Rowe, R.K. 2014. Service life of HDPE geomembranes subjected to elevated temperatures. Journal of Hazardous, Toxic, and Radioactive Waste, 18 (1): 16-26.

Jakob, M. 1949. Heat Transfer, vol. 1. Wiley.

Katsumi, T., Ishimori H., and Fukagawa, R. 2008. Evaluating methods to modify the chemical resistance of geosynthetic clay liners. Proceedings 4th Asian Regional Conference on Geosynthetics. 526-531 
Kanno, T., and Wakamatsu, H. 1992. Water uptake and swelling properties of unsaturated bentonite buffer materials. Canadian Geotechnical Journal, 29(6): 1102-1107.

Koerner, G. R., and Koerner, R. M. 2006. Long-term temperature monitoring of geomembranes at dry and wet landfills. Geotextiles and Geomembranes, 24(1): 72-77.

Lake, C.B., and Rowe, R.K. 2000. Swelling characteristics of needlepunched, thermally treated geosynthetic clay liners. Geotextiles and Geomembranes, 18: 77-101

Lee, J.O., Lim, J.G., Kang, I.M., and Kwon, S. 2012. Swelling pressures of compacted Ca-bentonite. Engineering Geology, 129-130: 20-26.

Lu, H., Walton, J.C., and Swifte, A.H.P. 2001. Desalination coupled with salinity-gradient solar ponds. Desalination 136: 13-23.

Petrov, R.J., and Rowe, R.K. 1997. Geosynthetic clay liner compatibility by hydraulic conductivity testing: Factors impacting performance. Canadian Geotechnical Journal, 34 (6), 863-885.

Pusch, R. 1980. Water uptake, migration and swelling characteristics of unsaturated and saturated, highly compacted bentonite: Swedish Nuclear Fuel Supply Company.

Pusch, R. 1982. Mineral-water interactions and their influence on the physical behavior of highly compacted Na bentonite. Canadian Geotechnical Journal, 19(3): 381-387.

Pusch, R., and Hokmark, H. 1990. Basic model of water and gas flow through smectite clay buffers. Engineering Geology 28 (3-4): 379-389.

Rayhani, M.T., Rowe, R.K., Brachman, R.W.I., Take' W.A., and Siemens, G. 2011. Factors affecting GCL hydration under isothermal conditions, Geotextiles and Geomembranes, 29(6):525-533.

Rentz, A., Take W.A., Brachman, R.W.I., and Rowe, R.K. 2015. Effect of geomembrane colour and cover soil on solar-driven down slope bentonite erosion from a GCL. Geosynthetics International, 22(1):78-92.

Rouf, M.A., Bouazza, A., Singh, R.M., Gates, W.P., and Rowe, R.K. 2016a. Water vapour adsorption and desorption in GCLs. Geosynthetics International, 23(2):86-99.

Rouf, M.A., Bouazza, A., Singh, R.M., Gates, W.P., and Rowe, R.K. 2016b. A gas flow unified measurement system for measuring sequentially gas diffusion and gas permeability of partially hydrated geosynthetic clay liners. Canadian Geotechnical Journal, 53 (6): 1000-1012

Rowe, R. K. 2005. Long-term performance of contaminant barrier systems. Geotechnique 55(9): 631-678.

Rowe, R.K. 2012. Short and long-term leakage through composite liners, The $7^{\text {th }}$ Arthur Casagrande Lecture, Canadian Geotechnical Journal, 49(2): 141-169.

Rowe, R.K. 2014. Performance of GCLs in liners for landfill and mining applications. Environmental Geotechnics, 1(1): 3-21 
Saba, S., Barnichon, J.D., Cui, Y.J., Tang, A.M., and Delage, P. 2014. Microstructure and anisotropic swelling behaviour of compacted bentonite/sand mixture. Journal of Rock Mechanics and Geotechnical Engineering, 6(2): 126-132.

Southen, J.M., and Rowe, R.K. 2005. Thermally induced desiccation of geosynthetic clay liners in landfill basal liner applications. ASCE Geotechnical Special Publication 142: 1-10

Southen, J.M., and Rowe, R.K. 2011. Numerical modelling of thermally induced desiccation of geosynthetic clay liners observed in laboratory experiments. Geosynthetics International 18 (5): 289-303.

Silva, G., and Almanza, R. 2009. Use of clays as liners in solar ponds. Solar Energy 83 (6):905-919.

Singh, R.M., and Bouazza, A. 2013. Thermal conductivity of geosynthetics. Geotextiles and Geomembranes 39: 1-8.

Smith, S.E. 2008. Emerging issues in heap leaching technology. In Proceedings of 4th European Conference on Geosynthetics. Edinburgh, CD-Rom.

Take, W.A., Watson, E., Brachman, R.W.I., and Rowe, R.K. 2012. Thermal expansion and contraction of geomembrane liners subjected to solar exposure and backfilling. Journal of Geotechnical and Geoenvironmental Engineering 138 (11): 1387-1397.

Take, W.A., Rowe, R.K., Brachman, R.W.I., and Arnepalli, D.N. 2015. Thermal exposure conditions for a composite liner with a black geomembrane exposed to solar radiation. Geosynthetics International, 22(1): 93-109.

Tang, A.M., Cui, Y.J., and Le, T.T. 2008. A study on thermal conductivity of compacted bentonites. Applied Clay Science, 41 (3-4): 181-189.

Tarnawski, V.R., Momose, T., and Leong, W.H. 2011. Thermal conductivity of standard sands II. Saturated Conditions. International Journal of Thermophysics 32(5): 984-1005

Thiel, R., and Smith, M.E. 2004. State of the practice review of heap leach design issues. Geotextiles and Geomembranes 22: 555-568.

Vangpaisal, T., and Bouazza, A. 2004. Gas permeability of partially hydrated geosynthetic clay liners. Journal of Geotechnical and Geoenvironmental Engineering 130 (1): 93-102.

Wang, Q., Tang, A.M., Cui, Y.J., Delage, P., and Gatmiri, B. 2012. Experimental study on the swelling behaviour of bentonite/claystone mixture. Engineering Geology, 124(1): 59-66.

Winterkorn, H.F., and Eyring, H. 1946. Theoretical aspects of water accumulation in cohesive subgrade soils. Proceedings of the Highway Research Board 25: 422-434.

Xie, J.L., Liu, Y.M., and Jiang, W.J. 2012. Measurement of thermal conductivity of compacted GMZ001 bentonite. Proceedings $2^{\text {nd }}$ ISRM International Young Scholar's Symposium on Rock Mechanics, 211-214. 
Yesiller, N., Hanson, J.L., and Liu, W.L. 2005. Heat generation in municipal solid waste landfills. Journal of Geotechnical and Geoenvironmental Engineering, 131(11): 1330-1344

Yesiller, N., Hanson, J.L., and Yee, E.H. 2015. Waste heat generation: A comprehensive review. Waste Management 42: 166-179

Yoshida, H., Hozumi, H., and Tanaka, N. 1996. Theoretical study on temperature distribution in a sanitary landfill. Proceedings $2^{\text {nd }}$ International Congress on Environmental Geotechnics, Osaka, Japan, 323-328.

Yu, K.L., Singh, R.M., Bouazza, A., and Bui, H.H. 2015. Determining soil thermal conductivity through numerical simulation of a heating test on a heat exchanger pile. Journal of Geotechnical and Geological Engineering, 33(2): 239-252. 


\section{Figure captions}

Figure 1: Histogram of mass per area (at the as received gravimetric water content) of (a) GCL-1 specimens and (b) GCL-2 specimens

Figure-2: Water uptake under various vertical stresses versus time: (a) GCL-1 and (b) GCL-2

Figure 3: Typical change in thickness (at a vertical stress of $25 \mathrm{kPa}$ ) of bentonite cakes: (a) Bentonite-1 and (b) Bentonite-2

Figure 4: Gravimetric water content variation (wetting) with time (at $25 \mathrm{kPa}$ ) of bentonite cakes: (a) Bentonite-1 and (b) Bentonite-2

Figure 5: Schematic diagram of the thermo-cell

Figure 6: Effect of vertical stress on the thermal conductivity of: (a) GCL-1 and (b) GCL-2

Figure 7: Relationship between GCL thermal conductivity and bulk void ratio at their target gravimetric water contents: (a) GCL-1 and (b) GCL-2

Figure 8: Thermal conductivity against apparent degree of saturation: (a) GCL-1 and (b) GCL-2

Figure 9: Change in thermal conductivity of bentonite and parent GCL with gravimetric water content (25 kPa stress): (a) GCL-1 and (b) GCL-2

Figure 10: Variation of thermal conductivity with gravimetric water content for Bentonite-1 and Bentonite-2

Figure 11: Thermal conductivity versus degree of saturation of Bentonite-1 and Clay-1

Figure 12: Thermal conductivity of Bentonite-1 cake and different components of GCL-1

Figure 13: Comparison of measured and estimated (revised) thermal conductivity versus gravimetric water content for GCL-1

Figure 14: Measured vs estimated (revised) thermal conductivity of GCL-1

Figure 15: Thermal conductivity variation of GCL-1 and GCL-2 against apparent degree of saturation 

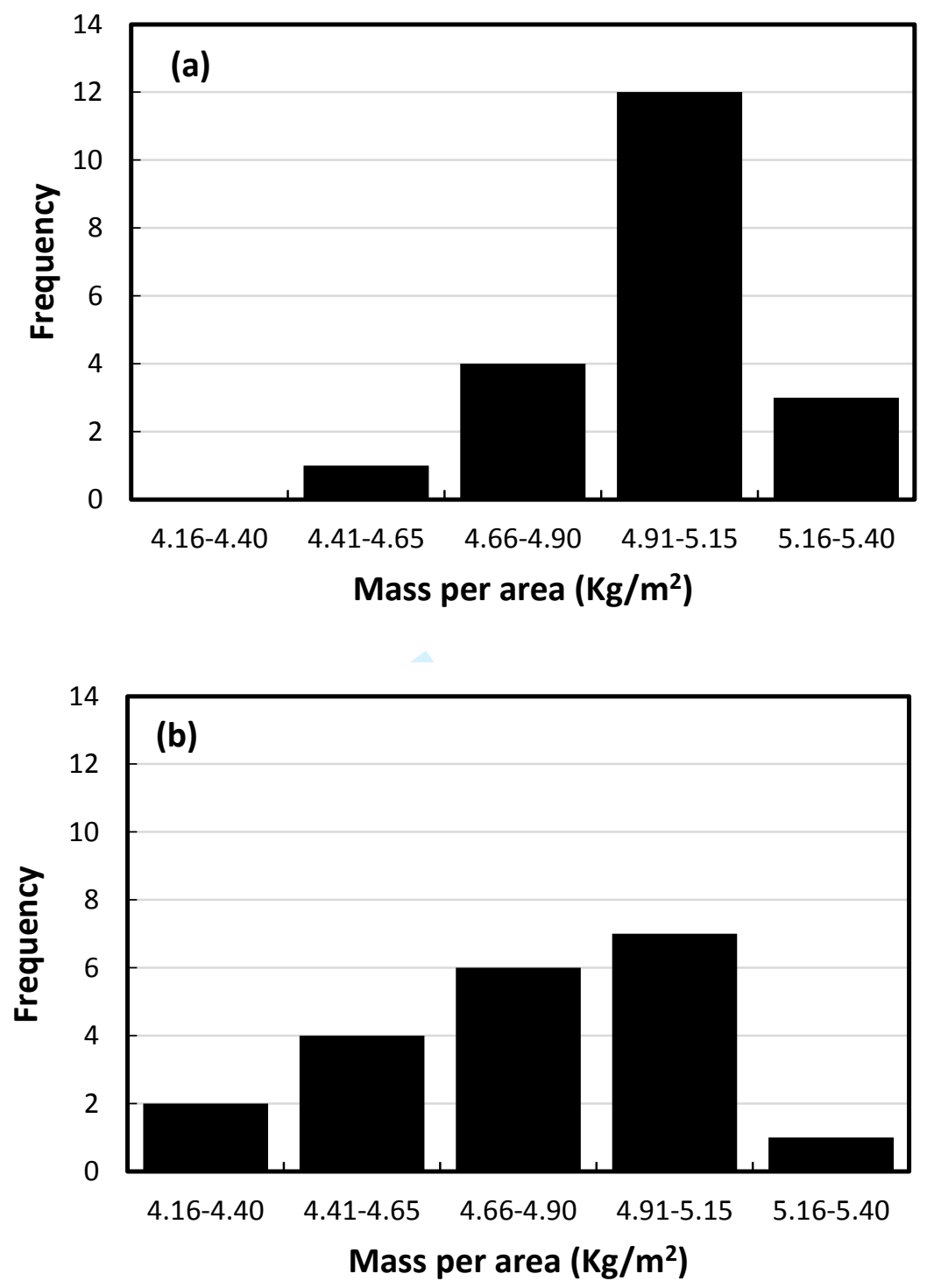

Figure 1: Histogram of mass per area (at the as received gravimetric water content) of (a) GCL-1 specimens and (b) GCL-2 specimens 

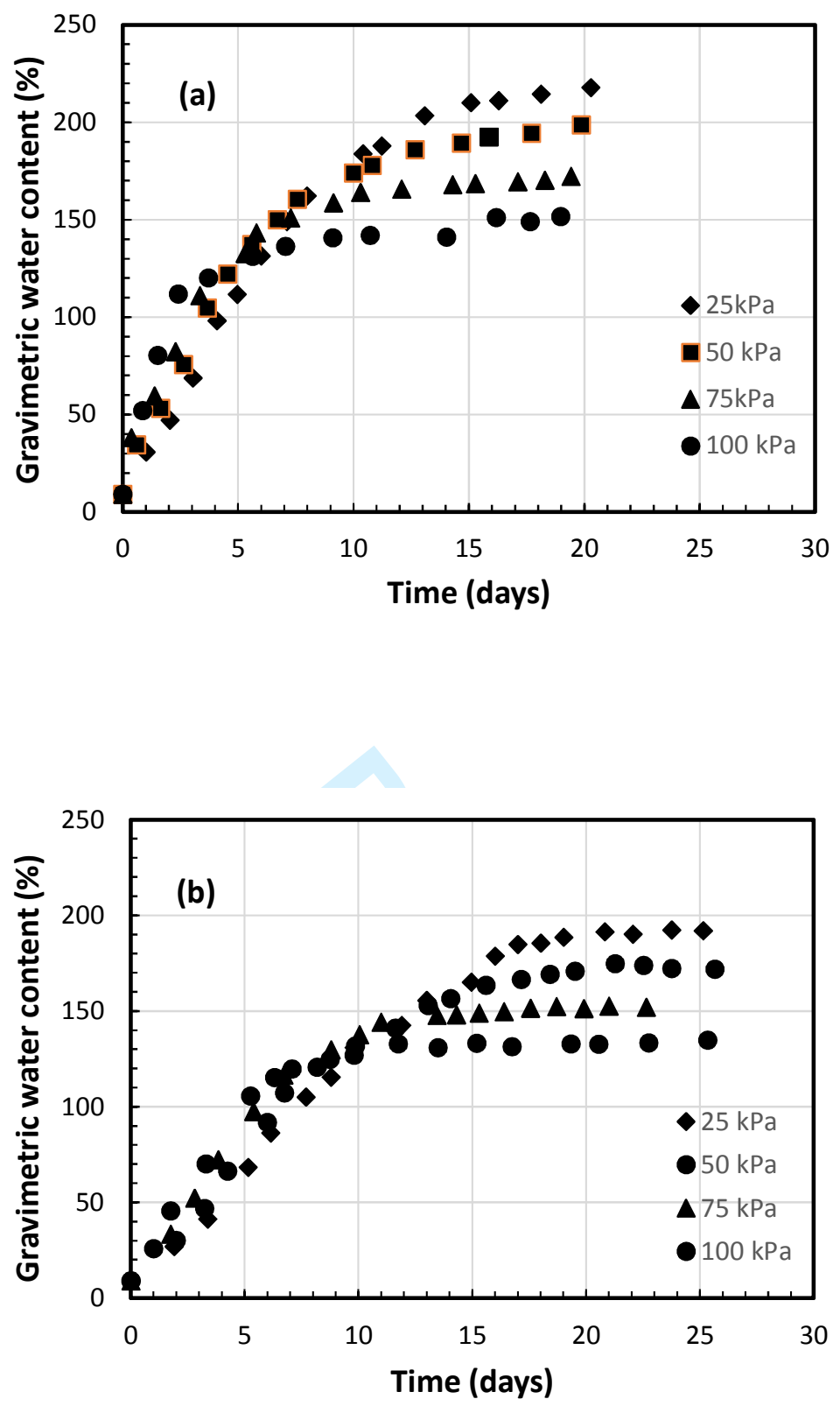

Figure-2: Water uptake under various vertical stresses versus time: (a) GCL-1 and (b) GCL-2 

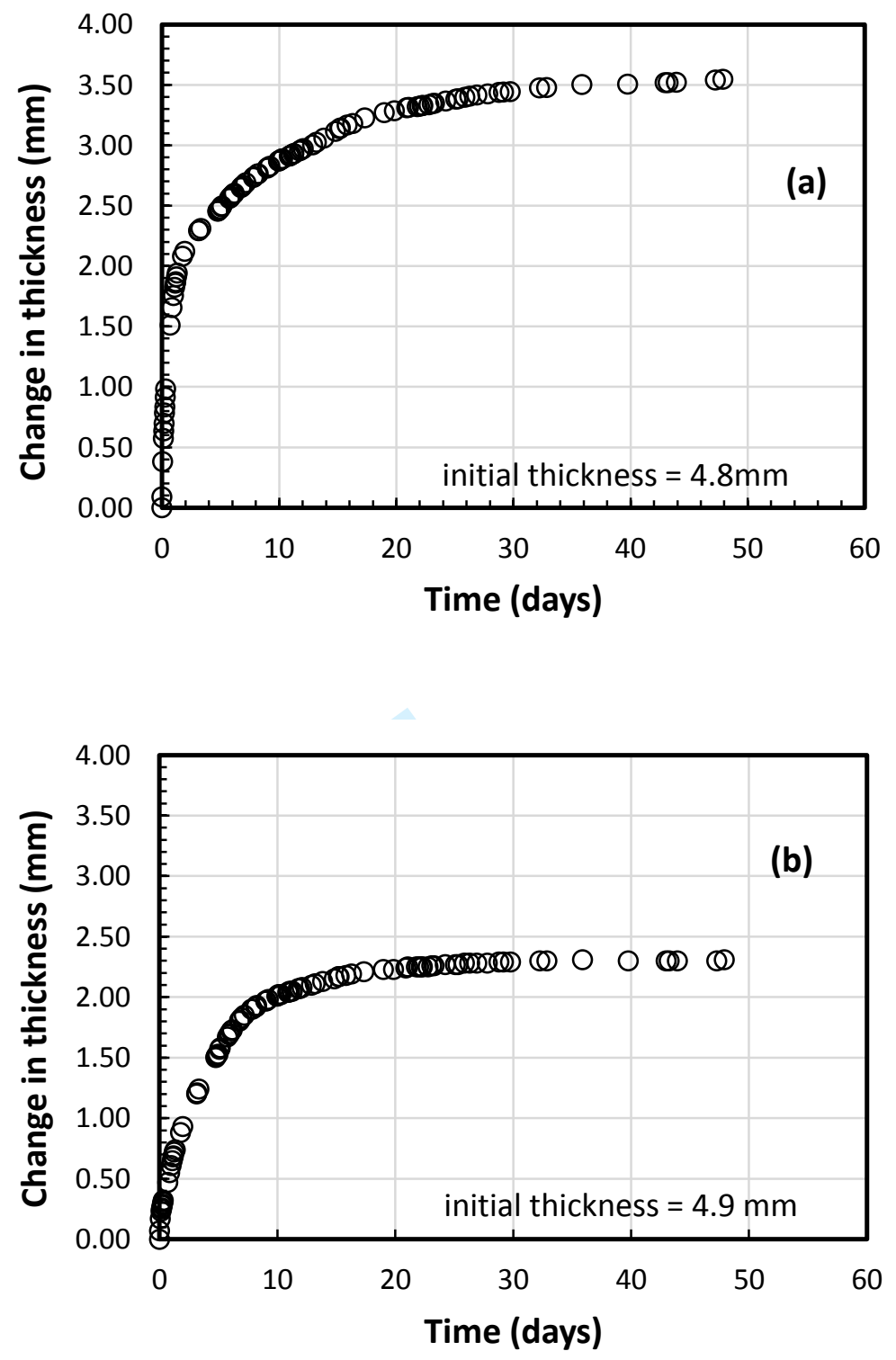

Figure 3: Typical change in thickness (at a vertical stress of $25 \mathrm{kPa}$ ) of bentonite cakes: (a) Bentonite-1 and (b) Bentonite-2 

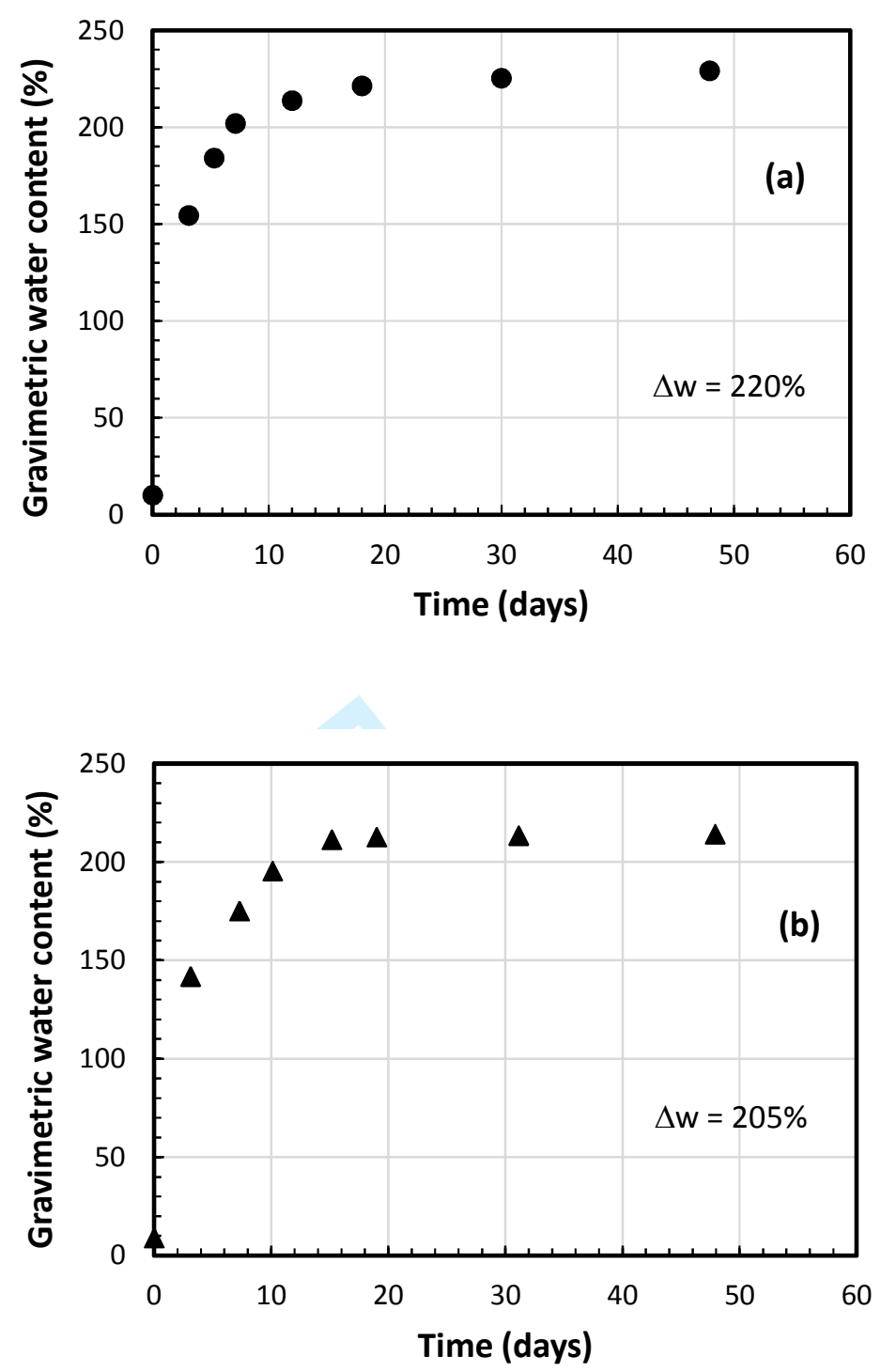

Figure 4: Gravimteric water content variation (wetting) with time (at $25 \mathrm{kPa}$ ) of bentonite cakes: (a) Bentonite-1 and (b) Bentonite-2 


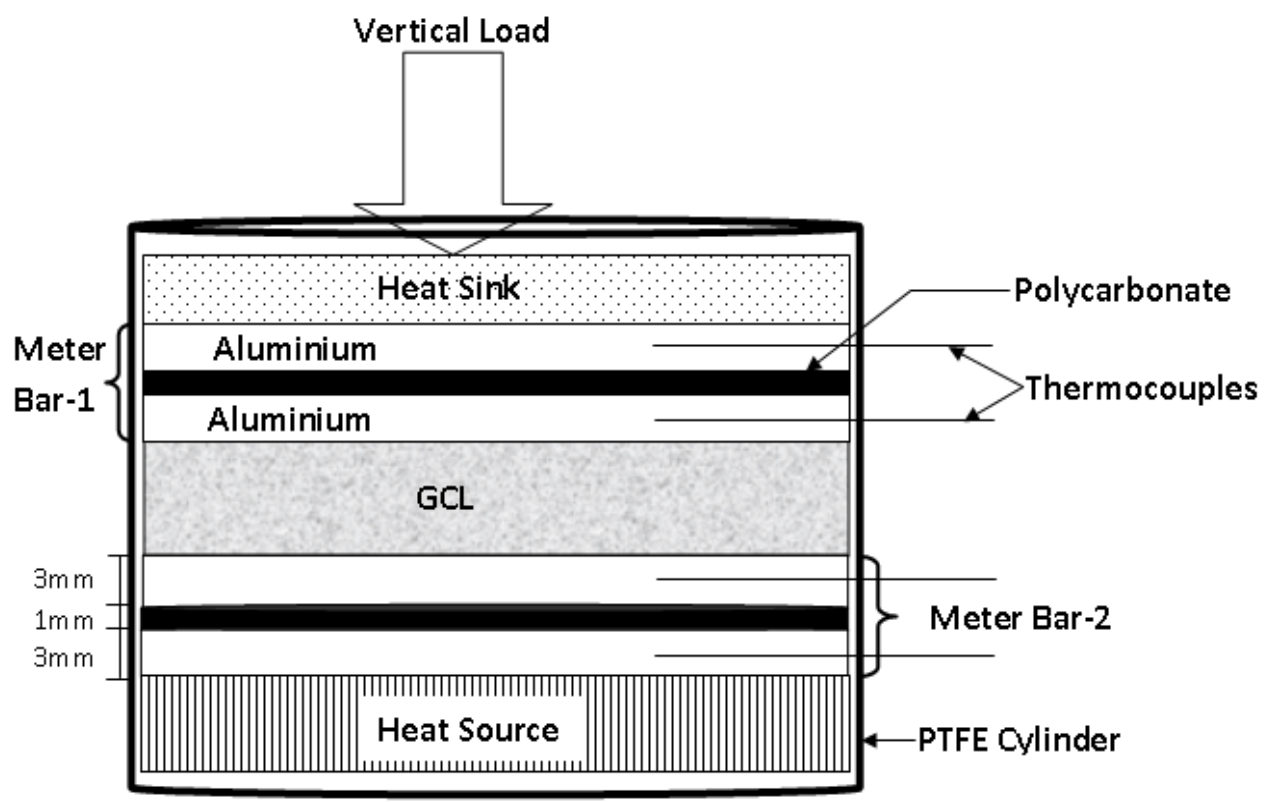

Figure 5: Schematic diagram of the thermo-cell 

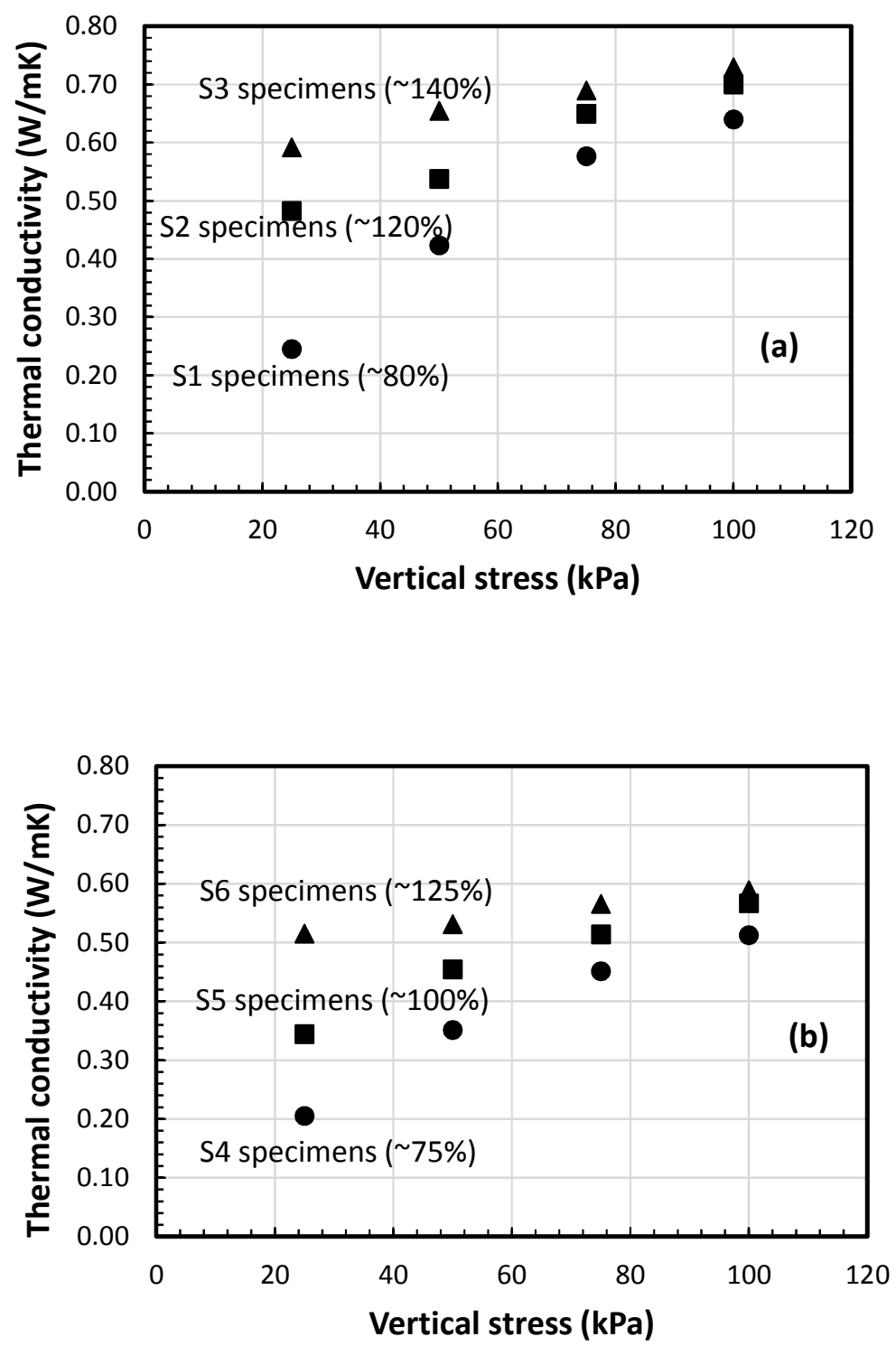

Figure 6: Effect of vertical stress on the thermal conductivity of: (a) GCL-1 and (b) GCL-2 

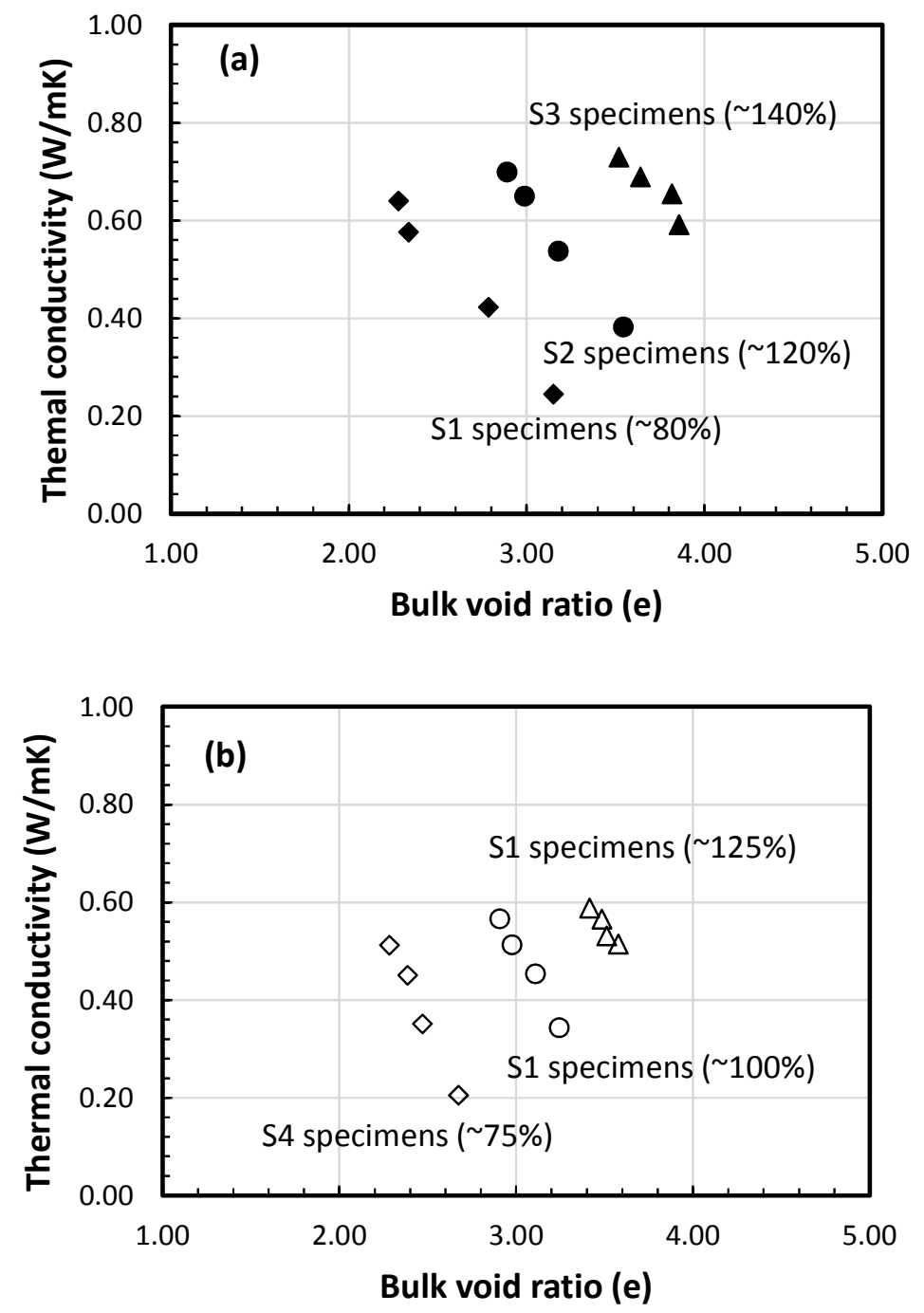

Figure 7: Relationship between GCL thermal conductivity and bulk void ratio at their target gravimetric water contents: (a) GCL-1 and (b) GCL-2 

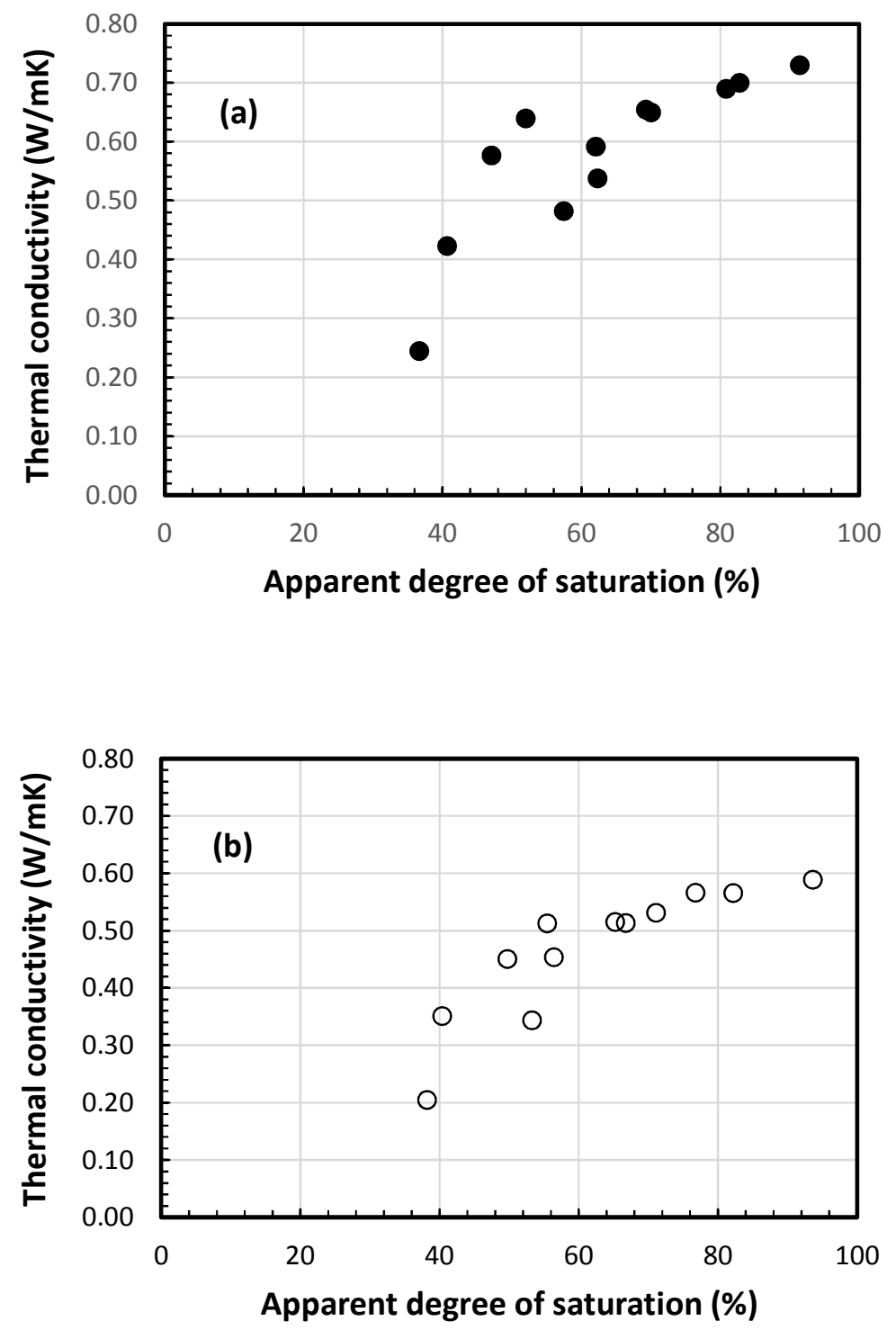

Figure 8: Thermal conductivity against apparent degree of saturation: (a) GCL-1 and (b) GCL-2 

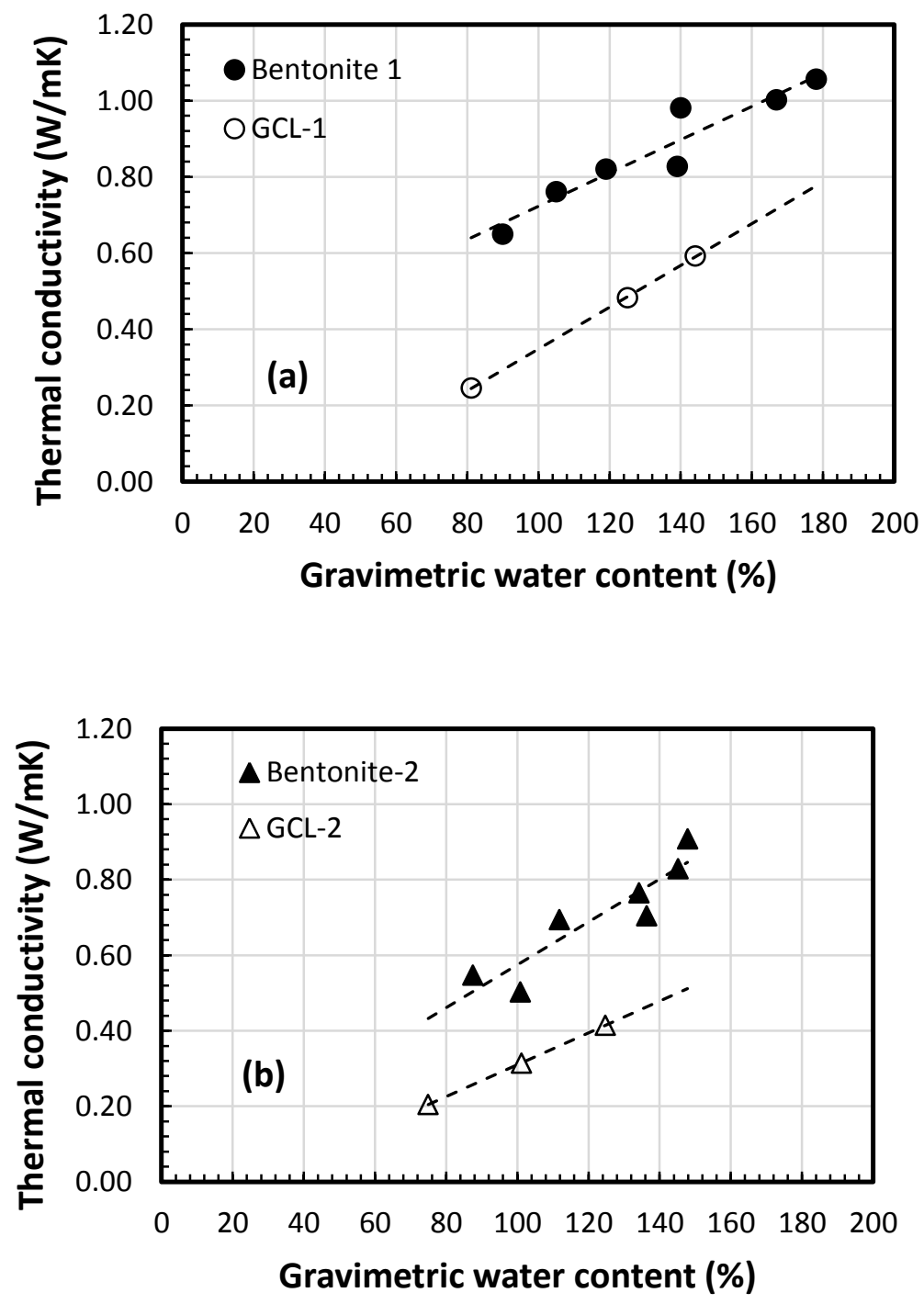

Figure 9: Change in thermal conductivity of bentonite and parent GCL with gravimetric water content (25 kPa stress): (a) GCL-1 and (b) GCL-2 


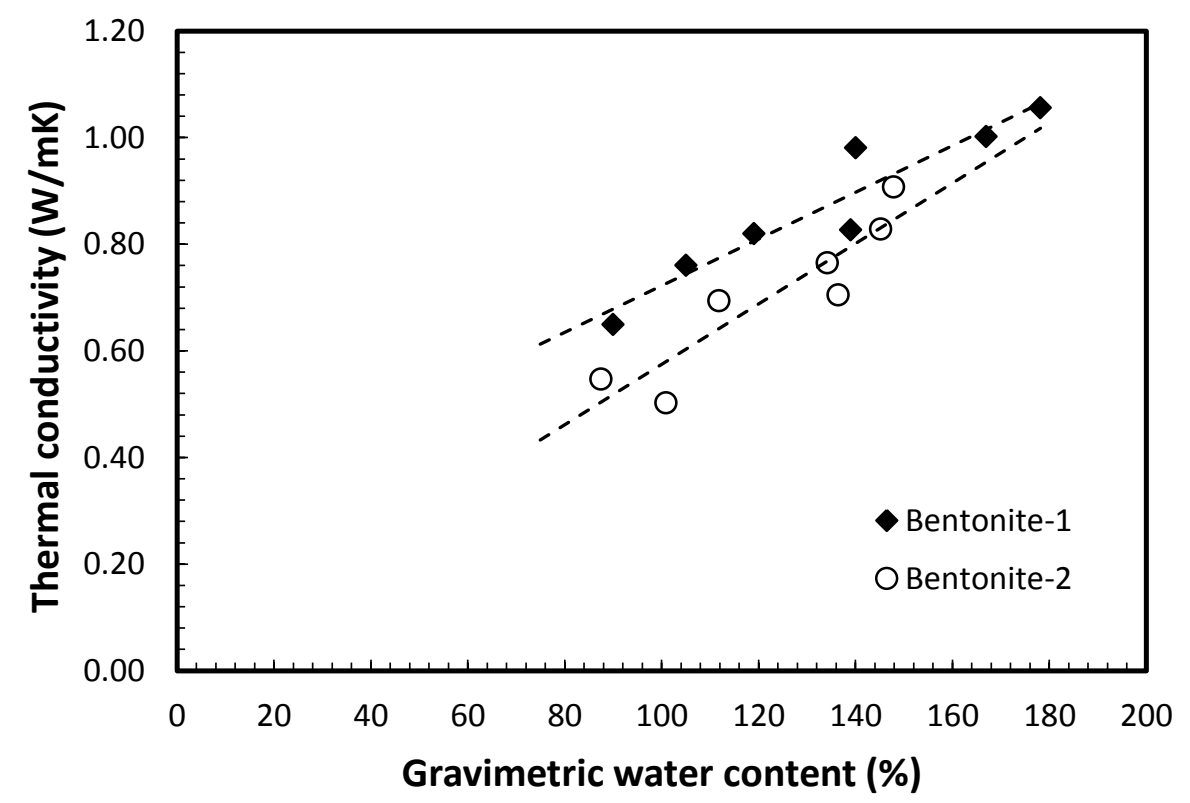

Figure 10: Variation of thermal conductivity with gravimetric water content for Bentonite-1 and Bentonite-2 


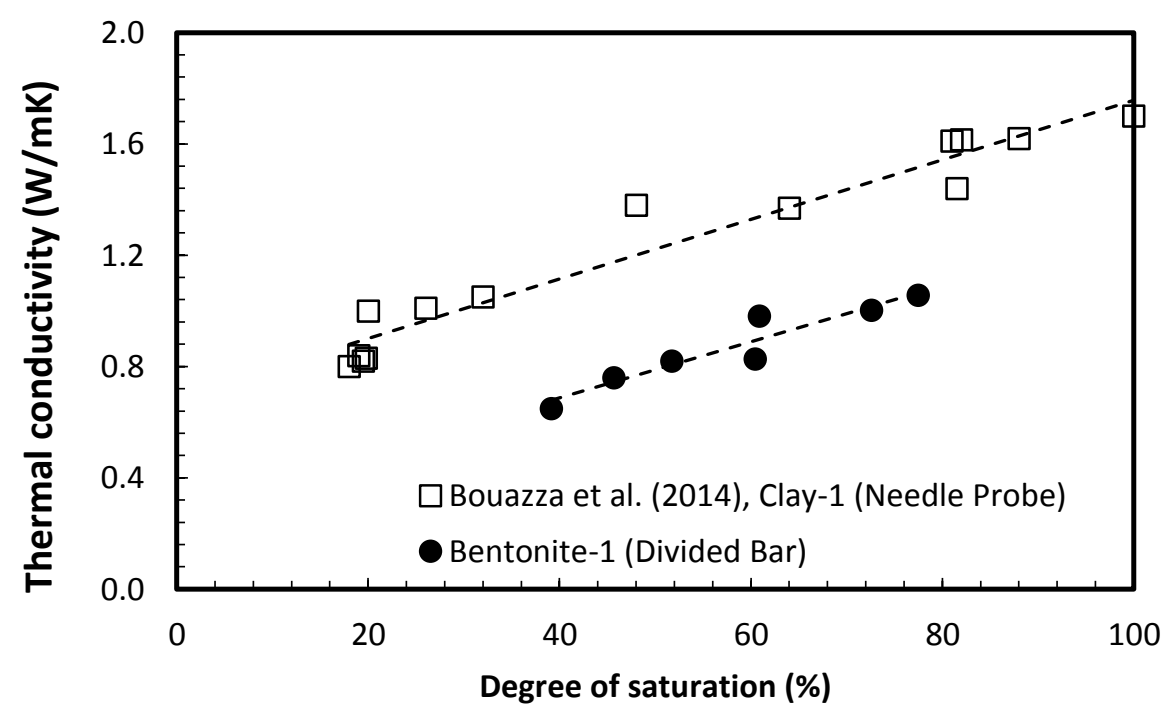

Figure 11: Thermal conductivity versus degree of saturation of Bentonite-1 and Clay-1 


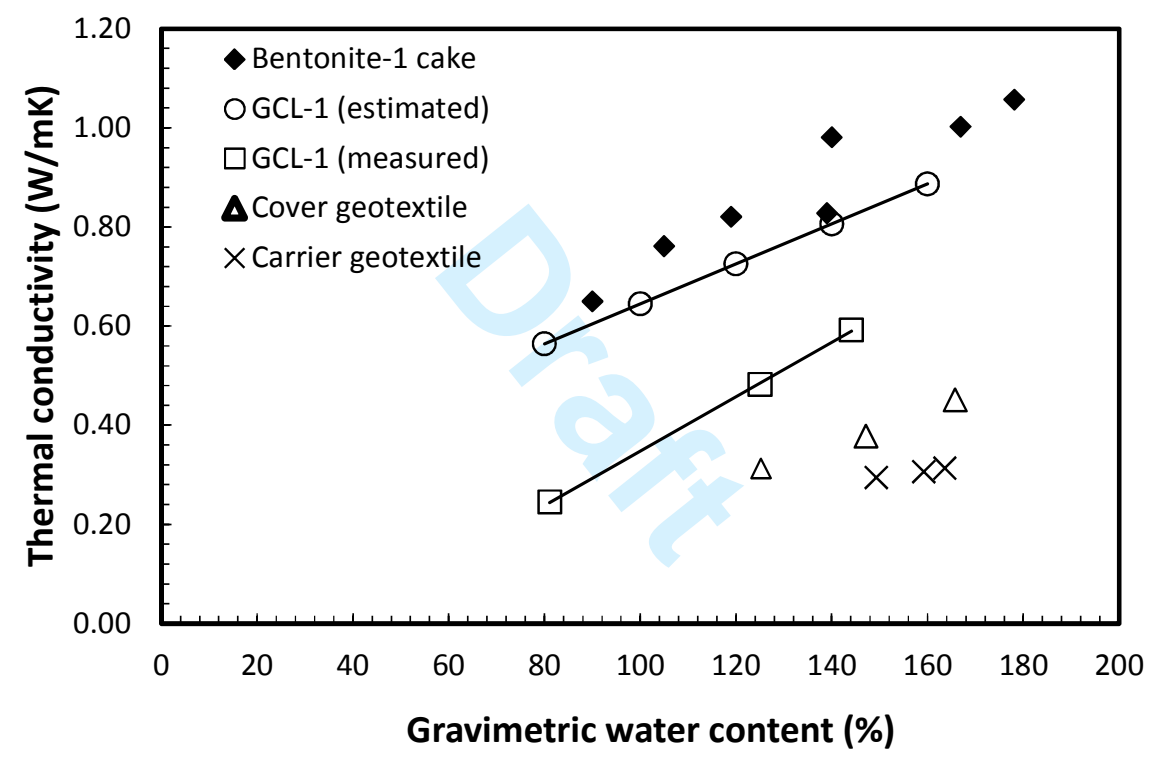

Figure 12: Thermal conductivity of Bentonite-1 cake and different components of GCL-1 


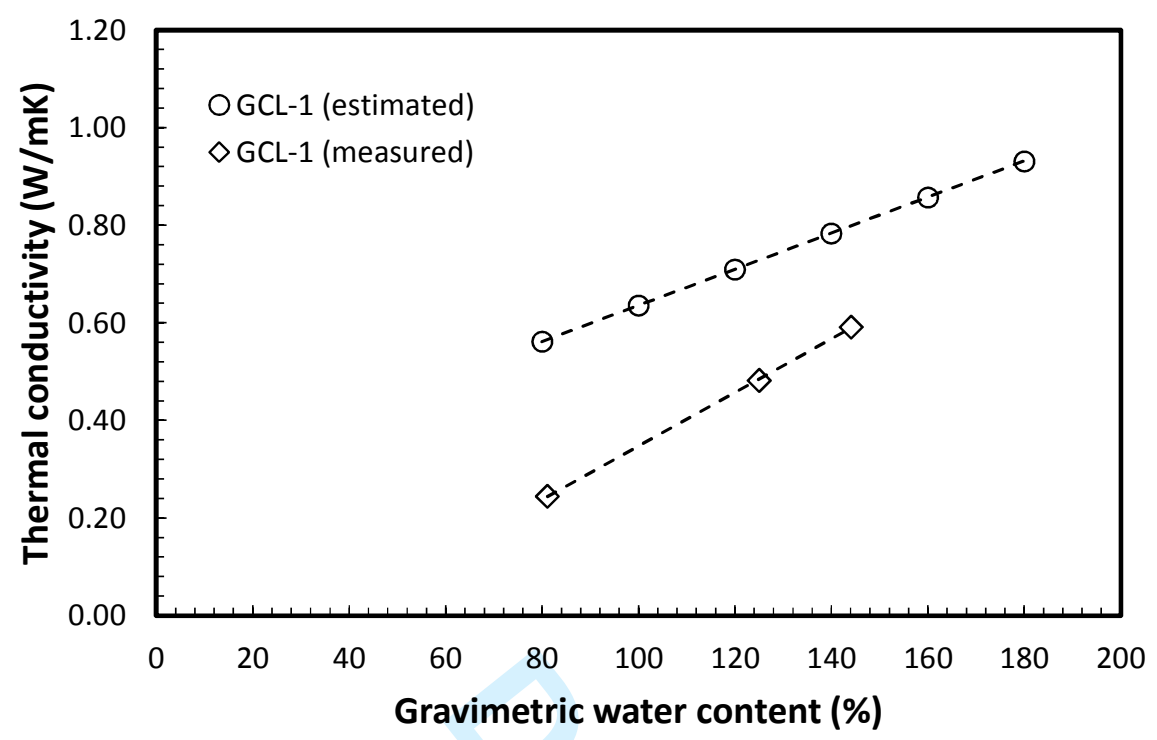

Figure 13: Comparison of measured and estimated (revised) thermal conductivity versus gravimetric water content for GCL-1 


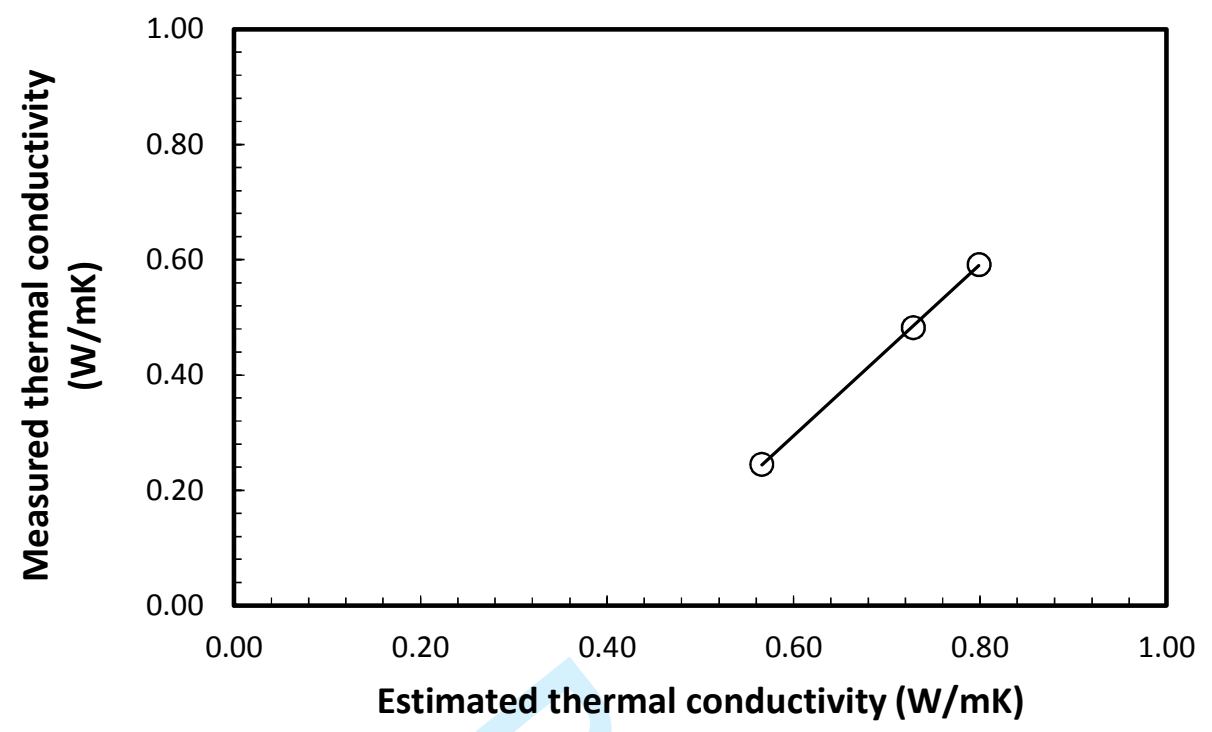

Figure 14: Measured vs estimated (revised) thermal conductivity of GCL-1 


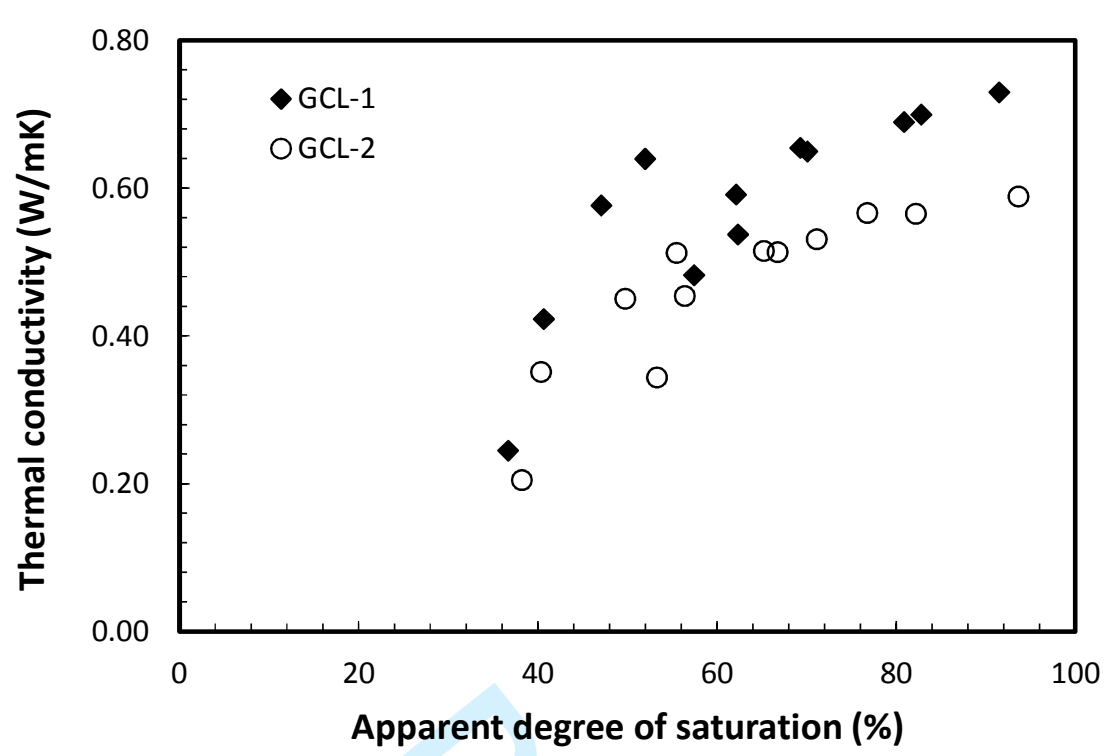

Figure 15: Thermal conductivity variation of GCL-1 and GCL-2 against apparent degree of saturation 
Table1: Physical properties of GCL-1 and GCL-2

\begin{tabular}{|c|c|c|c|c|}
\hline \multicolumn{2}{|l|}{ Property } & Units & GCL1 & GCL2 \\
\hline \multirow{2}{*}{\multicolumn{2}{|c|}{$\begin{array}{l}\text { As-received water content } \\
\text { GCL mass per area (@ as received water content), } \\
\mathrm{M}_{\mathrm{GCL}}\end{array}$}} & $(\%)$ & $9 \sim 11$ & $7 \sim 10$ \\
\hline & & $\mathrm{kg} / \mathrm{m}^{2}$ & $4.41 \sim 5.40$ & $4.16 \sim 5.40$ \\
\hline \multirow{2}{*}{\multicolumn{2}{|c|}{$\begin{array}{l}\text { Bentonite free swell index } \\
\text { Bentonite mass per area (@as received water } \\
\text { content), } \mathrm{M}_{\mathrm{b}}\end{array}$}} & $\mathrm{ml} / 2 \mathrm{~g}$ & 25 & 26 \\
\hline & & $\mathrm{kg} / \mathrm{m}^{2}$ & $3.64 \sim 4.63$ & $3.76 \sim 5.00$ \\
\hline \multirow[t]{3}{*}{ Cover geotextile (PP) } & Type & - & NW & NW \\
\hline & Mass per area, $\mathrm{M}_{\mathrm{GU}}$ & $\mathrm{kg} / \mathrm{m}^{2}$ & 0.34 & 0.25 \\
\hline & Thickness & $\mathrm{mm}$ & $2.52 \sim 2.65$ & $1.48 \sim 1.94$ \\
\hline \multirow[t]{3}{*}{ Carrier geotextile (PP) } & Type & - & $\mathrm{W}+\mathrm{NW}$ & W \\
\hline & Mass per area, $\mathrm{M}_{\mathrm{GL}}$ & $\mathrm{kg} / \mathrm{m}^{2}$ & 0.47 & 0.15 \\
\hline & Thickness & $\mathrm{mm}$ & $2.84 \sim 2.93$ & $0.54 \sim 0.66$ \\
\hline \multicolumn{3}{|l|}{ Bonding process } & $\begin{array}{l}\text { punched and } \\
\text { lly treated }\end{array}$ & Needle punched \\
\hline
\end{tabular}

$\mathrm{W}=$ Woven; $\mathrm{NW}=$ Nonwoven $\mathrm{PP}=$ Polypropylene 
Table 2: Mineralogical composition* of Bentonite-1, Bentonite-2 and Clay-1 (mass basis)

\begin{tabular}{lcccccccc}
\hline & $\begin{array}{c}\text { Quartz } \\
(\%)\end{array}$ & $\begin{array}{c}\text { Smectite } \\
(\%)\end{array}$ & $\begin{array}{c}\text { Cristobalite } \\
(\%)\end{array}$ & $\begin{array}{c}\text { Albite } \\
(\%)\end{array}$ & $\begin{array}{c}\text { Albite/ } \\
\text { Anorthite } \\
(\%)\end{array}$ & $\begin{array}{c}\text { Orthoclase } \\
(\%)\end{array}$ & $\begin{array}{c}\text { Calcite } \\
(\%)\end{array}$ & $\begin{array}{c}\text { Kaolinite } \\
(\%)\end{array}$ \\
\hline Bentonite-1 & 14 & 74 & 8 & $<1$ & 4 & - & - & - \\
Bentonite-2 & 4 & 82 & - & - & 3 & 6 & 5 & - \\
Clay-1 & 53 & 29 & - & 1 & - & 1 & - & 16 \\
\hline
\end{tabular}

* as determined by quantitative powder X-ray diffraction and Reitveld refinement (Mineralogical Services, CSIRO Land and Water, Adelaide). 
Table 3: Testing condition, initial and final gravimetric water contents of the GCL specimens $\left(\Delta \mathrm{T}=10^{\circ} \mathrm{C}\right.$ for all the tests)

\begin{tabular}{|c|c|c|c|c|c|c|c|}
\hline & & & $\begin{array}{l}\text { Target } \\
\text { gravimetric } \\
\text { water } \\
\text { content }\end{array}$ & $\begin{array}{l}\text { Initial } \\
\text { gravimetric } \\
\text { water } \\
\text { content }\end{array}$ & $\begin{array}{l}\text { Gravimetric } \\
\text { water } \\
\text { content } \\
\text { before } \\
\text { application } \\
\text { of thermal } \\
\text { gradient } \\
\quad(\%)\end{array}$ & $\begin{array}{l}\text { Final } \\
\text { gravimetric } \\
\text { water } \\
\text { content }\end{array}$ & $\begin{array}{c}\text { Vertical } \\
\text { stress }\end{array}$ \\
\hline \multirow{12}{*}{ تِ } & $\overline{S 1}$ & Specimen-1 & 80 & 82.05 & 81.80 & 81.11 & 25 \\
\hline & specimens & Specimen-2 & 80 & 81.55 & 80.18 & 79.82 & 50 \\
\hline & & Specimen-3 & 80 & 83.70 & 82.76 & 82.29 & 75 \\
\hline & & Specimen-4 & 80 & 84.45 & 81.69 & 81.07 & 100 \\
\hline & S2 & Specimen-5 & 120 & 126.49 & 125.82 & 125.04 & 25 \\
\hline & specimens & Specimen-6 & 120 & 125.59 & 123.98 & 123.75 & 50 \\
\hline & & Specimen-7 & 120 & 121.13 & 120.88 & 120.59 & 75 \\
\hline & & Specimen-8 & 120 & 128.05 & 126.03 & 125.39 & 100 \\
\hline & & Specimen-9 & 140 & 146.95 & 144.77 & 144.13 & 25 \\
\hline & specimens & Specimen-10 & 140 & 163.15 & 149.10 & 148.51 & 50 \\
\hline & & Specimen-11 & 140 & 169.4 & 144.98 & 144.18 & 75 \\
\hline & & Specimen-12 & 140 & 174.45 & 146.19 & 145.53 & 100 \\
\hline \multirow{12}{*}{ ְُ } & $\overline{\mathrm{S} 4}$ & Specimen-13 & 75 & 76.10 & 75.98 & 74.92 & 25 \\
\hline & specimens & Specimen-14 & 75 & 77.82 & 75.82 & 75.16 & 50 \\
\hline & & Specimen-15 & 75 & 77.92 & 75.09 & 74.86 & 75 \\
\hline & & Specimen-16 & 75 & 80.17 & 76.12 & 75.85 & 100 \\
\hline & S5 & Specimen-17 & 100 & 102.10 & 101.61 & 101.22 & 25 \\
\hline & specimens & Specimen-18 & 100 & 102.51 & 101.05 & 100.31 & 50 \\
\hline & & Specimen-19 & 100 & 103.18 & 100.89 & 100.49 & 75 \\
\hline & & Specimen-20 & 100 & 108.92 & 101.19 & 100.52 & 100 \\
\hline & S6 & Specimen-21 & 125 & 125.69 & 125.08 & 124.78 & 25 \\
\hline & specimens & Specimen-22 & 125 & 138.82 & 125.70 & 125.28 & 50 \\
\hline & & Specimen-23 & 125 & 139.19 & 125.01 & 124.16 & 75 \\
\hline & & Specimen-24 & 125 & 140.92 & 124.52 & 123.98 & 100 \\
\hline
\end{tabular}


Table 4: Final equilibrium gravimetric water content, $w_{\text {ref }}$, of the GCLs under different vertical stresses (with a plentiful supply of water so hydration is not limited by the availability of water).

\begin{tabular}{ccc}
\hline $\begin{array}{c}\text { Vertical stress } \\
(\mathrm{kPa})\end{array}$ & $\begin{array}{c}w_{\text {ref }}-\text { GCL-1 } \\
(\%)\end{array}$ & $\begin{array}{c}w_{\text {ref }}-\text { GCL-2 } \\
(\%)\end{array}$ \\
\hline 25 & 218 & 192 \\
50 & 198 & 172 \\
75 & 172 & 153 \\
100 & 151 & 136 \\
\hline
\end{tabular}

